\title{
Report on FY 2021 Fabrication and Testing of Qualified Alloy 709 Welds at ORNL
}

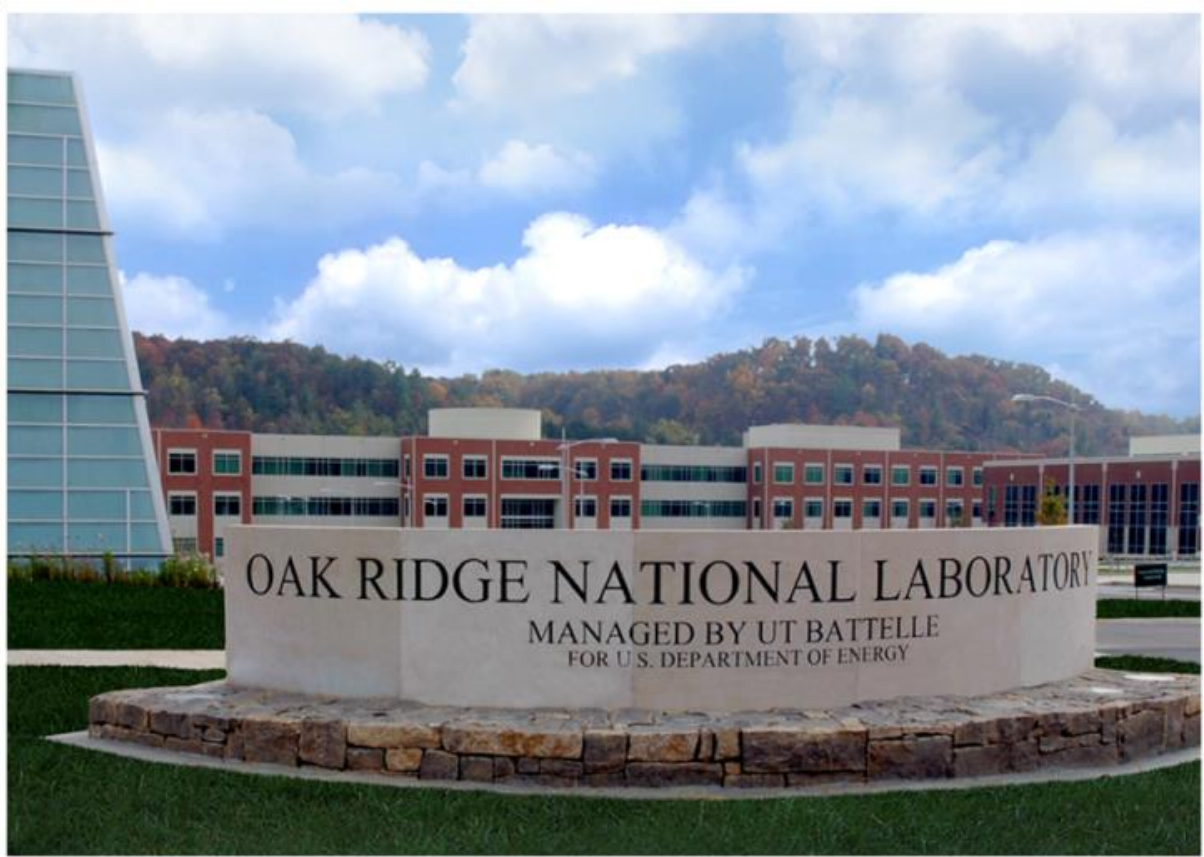

Zhili Feng

Tao Dai

Doug Kyle

Yiyu Wang

Yanli Wang

September 2021

Approved for public release.

Distribution is unlimited. 


\title{
DOCUMENT AVAILABILITY
}

Reports produced after January 1, 1996, are generally available free via US Department of Energy (DOE) SciTech Connect.

Website http://www.osti.gov/scitech/

Reports produced before January 1, 1996, may be purchased by members of the public from the following source:

\author{
National Technical Information Service \\ 5285 Port Royal Road \\ Springfield, VA 22161 \\ Telephone 703-605-6000 (1-800-553-6847) \\ TDD 703-487-4639 \\ Fax 703-605-6900 \\ E-mail info@ntis.gov \\ Website http://www.ntis.gov/help/ordermethods.aspx
}

Reports are available to DOE employees, DOE contractors, Energy Technology Data Exchange representatives, and International Nuclear Information System representatives from the following source:

Office of Scientific and Technical Information

PO Box 62

Oak Ridge, TN 37831

Telephone 865-576-8401

Fax 865-576-5728

E-mail reports@osti.gov

Website http://www.osti.gov/contact.html

\begin{abstract}
This report was prepared as an account of work sponsored by an agency of the United States Government. Neither the United States Government nor any agency thereof, nor any of their employees, makes any warranty, express or implied, or assumes any legal liability or responsibility for the accuracy, completeness, or usefulness of any information, apparatus, product, or process disclosed, or represents that its use would not infringe privately owned rights. Reference herein to any specific commercial product, process, or service by trade name, trademark, manufacturer, or otherwise, does not necessarily constitute or imply its endorsement, recommendation, or favoring by the United States Government or any agency thereof. The views and opinions of authors expressed herein do not necessarily state or reflect those of the United States Government or any agency thereof.
\end{abstract}




\title{
REPORT ON FY 2021 FABRICATION AND TESTING OF QUALIFIED ALLOY 709 WELDS AT ORNL
}

\author{
Zhili Feng \\ Tao Dai \\ Doug Kyle \\ Yiyu Wang \\ Yanli Wang
}

September 2021

Prepared by

OAK RIDGE NATIONAL LABORATORY

Oak Ridge, TN 37831-6283

managed by

UT-BATTELLE, LLC

for the

US DEPARTMENT OF ENERGY

under contract DE-AC05-00OR22725 



\section{CONTENTS}

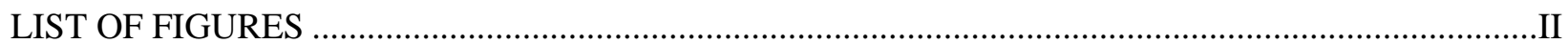

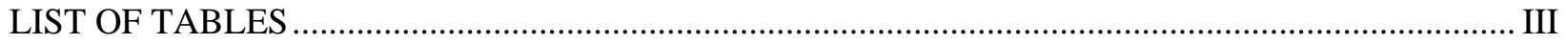

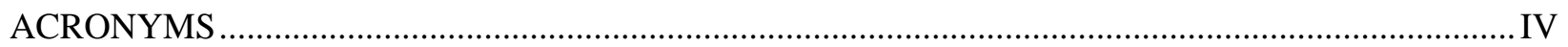

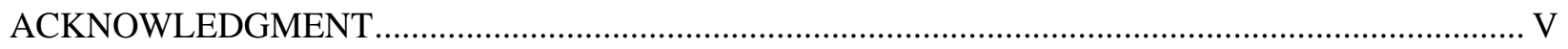

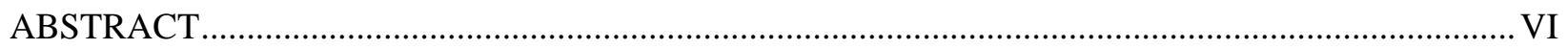

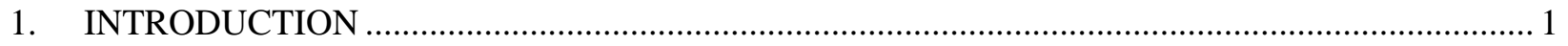

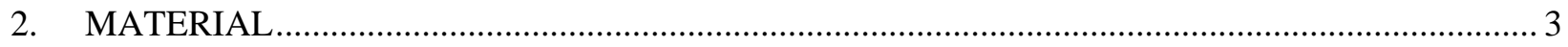

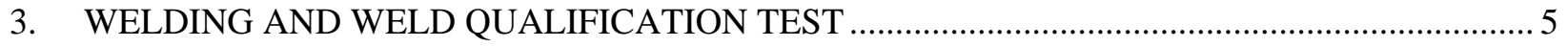

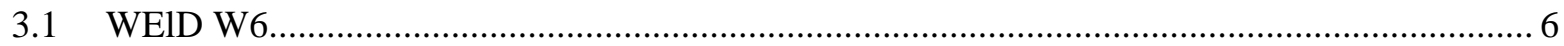

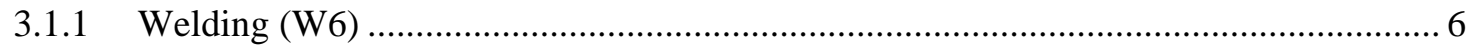

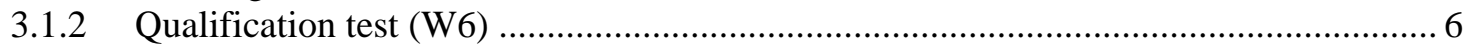

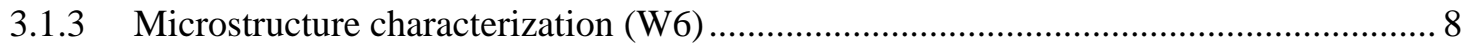

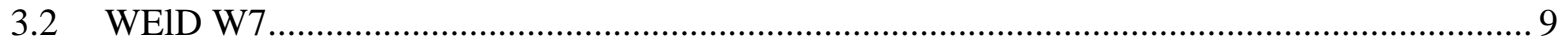

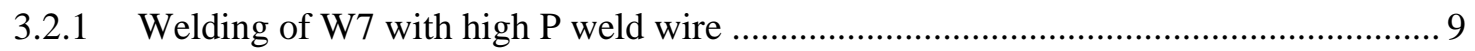

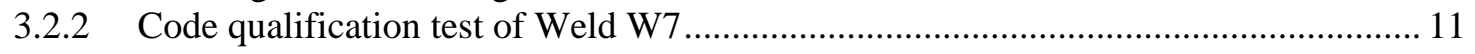

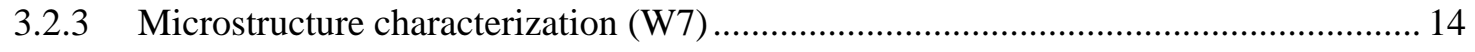

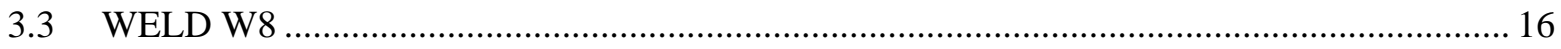

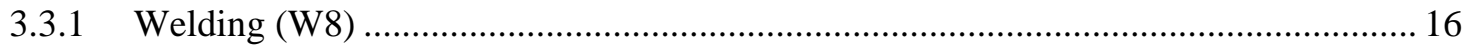

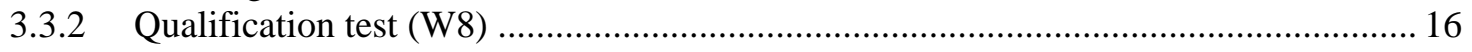

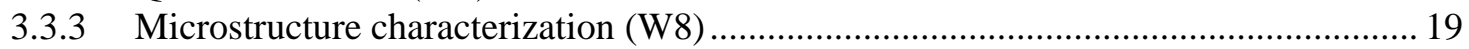

4. FABRICATION OF ALLOY 709 WELD TO SUPPORT ALLOY 709 WELD CODE CASE

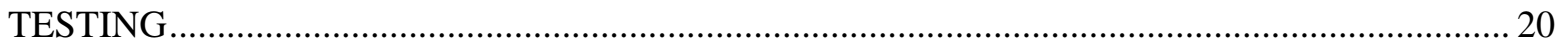

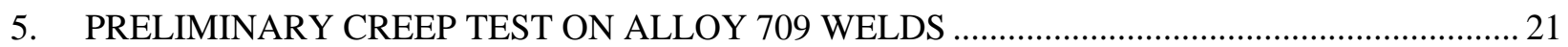

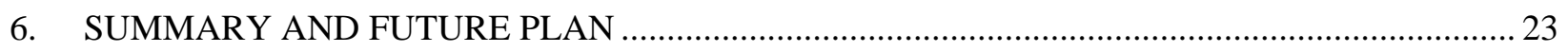

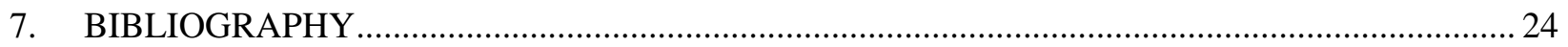




\section{LIST OF FIGURES}

Figure 1. Room temperature cross-weld tensile specimen geometry .................................................. 4

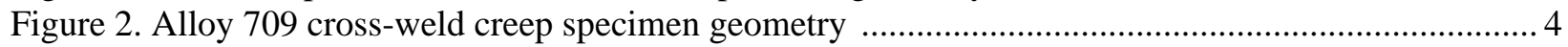

Figure 3. Single V-groove joint preparation details used in the study .............................................. 5

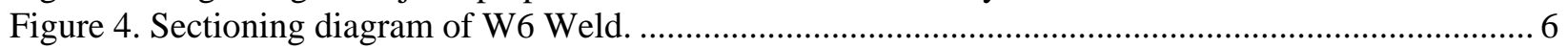

Figure 5. Room temperature cross-weld tensile results for Weld W6 ................................................. 7

Figure 6. Photograph of the room temperature cross-weld tensile test results from Weld W6 ................... 7

Figure 7. Cross-section view of Weld W6. No apparent weld defect or cracking were observed................ 8

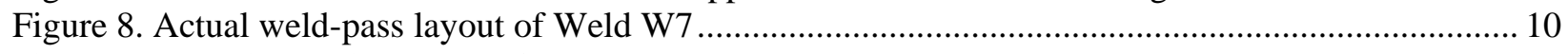

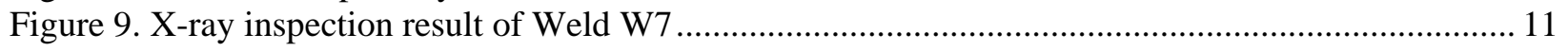

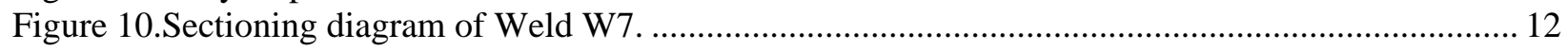

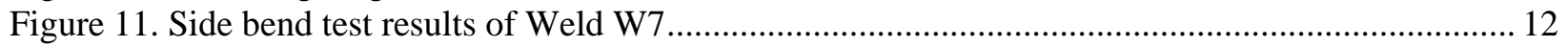

Figure 12. Room temperature cross-weld tensile results for Weld W7 ............................................... 13

Figure 13. Photograph of the room temperature cross-weld tensile specimens from Weld W7 ................ 13

Figure 14. Cross-section view and the weld defects observed in Weld W7 ........................................... 15

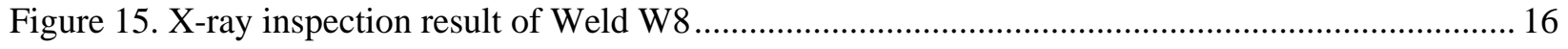

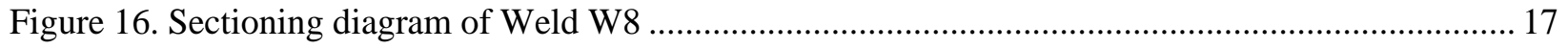

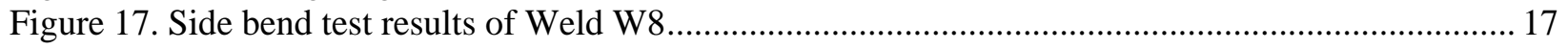

Figure 18. Room temperature cross-weld tensile results for Weld W8 ................................................. 18

Figure 19. Photograph of the room temperature cross-weld tensile specimens from Weld W8 ................ 18

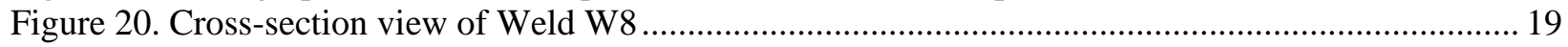

Figure 21. Photograph of the Alloy 709 production weld and X-ray NDE results................................. 20

Figure 22 Comparison of creep rupture testing results of welds and base metal of Alloy 709................ 22 


\section{LIST OF TABLES}

Table 1 Heat treatment conditions of base metal plates in this work...................................................... 3

Table 2. Chemical compositions of Alloy 709 materials (wt \%).......................................................... 3

Table 3. Combination of weld wire and base metal conditions investigated in this study ........................ 5

Table 4. Room temperature cross-weld tensile results for Weld W6 ...................................................... 8

Table 5. Welding parameters for Weld W7 (with 140wppm P weld wire) ........................................... 10

Table 6. Room temperature cross-weld tensile results for Weld W7 ....................................................... 14

Table 7. Room temperature cross-weld tensile results for Weld W8 ..................................................... 19

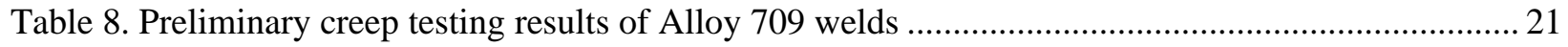




\section{ACRONYMS}

709 Program Alloy 709 Intermediate Term Test Program

AOD

ART

ASME

ASTM

DOE

ESR

GTAW

FCC

NDE

ORNL

SFR

SA

Argon-Oxygen-Decarburization

Advanced Reactor Technologies

The American Society of Mechanical Engineers

American Society for Testing and Materials. (aka, ASTM International)

Department of Energy

Electroslag remelting

Gas Tungsten Arc Welding

Face Centered Cubic

Nondestructive examination

Oak Ridge National Laboratory

Sodium Fast Reactor

Solution Annealed 


\section{ACKNOWLEDGMENT}

This research was sponsored by the US Department of Energy (DOE), under contract No. DE-AC0500OR22725 with Oak Ridge National Laboratory (ORNL), managed and operated by UT-Battelle LLC. Programmatic direction was provided by the Office of Nuclear Reactor Deployment of the DOE Office of Nuclear Energy.

The authors gratefully acknowledge the support provided by Sue Lesica, Federal Lead, Advanced Materials, Advanced Reactor Technologies (ART) Program; Brian Robinson, Federal Manager, ART Fast Reactors (FR) Campaign, Robert Hill of Argonne National Laboratory, National Technical Director, ART FR Campaign, and T.-L. Sham of Idaho National Laboratory, Technology Area Lead, Advanced Materials, ART Program.

The authors also wish to thank ORNL staff members Jian Chen and Lianshan Lin for reviewing this report. 


\begin{abstract}
Alloy 709 is a candidate construction material for the Sodium Fast Reactor (SFR). As part of the Alloy 709 ASME Code Case development team under the Advanced Reactor Technologies (ART) Program, this work covers the development of the technical basis for weld fabrication and weld qualification of Alloy 709. This report summarizes the research conducted in FY 2021 and relevant results from previous reporting periods, aimed at welding commercial heat of Alloy 709 plates of relatively high phosphorous $(P)$ level in support of ASME code case data package. Welding, code qualification tests, and associated microstructure characterization were carried out in determining the effect of $\mathrm{P}$ levels of weld wire on the weldability of the high P commercial heat of Alloy 709. The Alloy 709 weld creep strength was evaluated though preliminary creep testing.
\end{abstract}

All welds produced and investigated so far in this work have been on the first commercial heat of Alloy 709 with 140wppm P (the Carlson Heat 58776). Welds with three different P levels were produced by changing the $\mathrm{P}$ level of the weld wires from $20 \mathrm{wppm}$ to $140 \mathrm{wppm}$.

The study found that the Carlson Heat 58776 with 140wppm P can be welded with relative ease when using a low $\mathrm{P}(<20 \mathrm{wppm})$ weld wire with gas tungsten arc welding (GTAW) at typical welding input levels. Furthermore, preliminary cross weld creep tests showed little or no creep strength reduction in the weld region relative to that of the base metal. This established the basis to produce defect free weld with low $\mathrm{P}$ weld wire practice, and it has been adopted to produce an additional large size weld in support of the planned creep testing and others as part of the Alloy 709 Code Case data package. Meanwhile, studies on the restriction of the $\mathrm{P}$ level in the weld wire continued. When the $\mathrm{P}$ level in the weld wire increases to 140 wppm, micro cracks or micro fissures are observed in the weldment. This was caused by significant micro segregation of $\mathrm{P}$ at the solidification grain boundaries of the weld metal. It is possible to improve the weldability by adjusting the weld wire size to reduce the welding heat input. However, additional $\mathrm{R} \& \mathrm{D}$ is necessary to eliminate the micro-cracks at $140 \mathrm{wppm}$ level of P. Initial weld creep test indicated that the micro-cracks would potentially cause premature rupture under low-temperature and high-stress creep testing conditions, although they had minimal effect to weld creep strength under lower stress and higher temperature conditions. Finally, the weld fabricated using a weld wire with the medium P level (estimated at $80 \mathrm{wppm}$ ) passed the ASME Sec IX weld qualification requirement and showed improved weldability compared to the $140 \mathrm{wppm}$ case. Micro-cracks were still observed, but they were much smaller and the number density of these defects were much less than those at the 140wppm P level. Hightemperature creep testing of the medium P level weld has been planned and will be carried out in FY 2022. 


\section{INTRODUCTION}

Advanced materials can have a significant impact on flexibility, safety, and economics of the future sodium fast reactor (SFR). This is due to innovative designs and design simplifications that could be made possible using materials with enhanced mechanical properties. Improved materials performance also impacts safety through improved reliability and greater design margins. Improved material reliability could also result in reduced down time.

Alloy 709 is an advanced nitrogen-stabilized and niobium-strengthened austenitic stainless steel. Compared to a reference construction material 316H stainless steel for SFR, Alloy 709 has enhanced creep strength, good steam oxidation resistance and hot corrosion resistance. It is an attractive candidate construction material for SFR systems. Code qualification of Alloy 709 is underway as part of the development effort under the US Department of Energy, Advanced Reactor Technologies (ART) Program (Sham \& Natesan, 2017), to provide the technical basis necessary to support the regulatory requirements for structural materials required for advanced, non-light water reactors that could be deployed in the nearto-mid-term.

Welding is essential in construction of SFR structures. The code case qualification for SFR would require the development of a sound technical basis for welding of Alloy 709. It would include the development of welding guidelines with supporting testing results to fabricate ASME Section IX (ASME, 2019) qualified welds using weld wires with appropriately specified chemistry range, to eliminate solidification cracking, minimize stress relaxation cracking susceptibility, and retain the good high temperature mechanical properties, for selected heats meeting relevant ASTM/ASME chemistry specifications.

Alloy 709 is derived from NF709, i.e., TP310MoCbN (UNS S31025) specified in ASME BPVC.II SA213/SA-213M (ASME, 2021). NF709 seamless tube was developed by Nippon Steel Corporation in Japan for boiler tubing applications. Previous studies such as these by Nippon Steel (2013), suggested that NF709 has relatively good weldability. Alloy 709 matching filler metal and Alloy 625 filler metal were the two weld metals that Nippon Steel had recommended to weld seamless tubing. Performance of Alloy 709 weldment fabricated using Alloy 625 filler metal in sodium was found to be less than optimal during the Alloy 709 intermediate term testing program because of the high solubility of nickel in sodium. Weldment fabricated from Alloy 709 matching filler metal was found to have good sodium compatibility. However, earlier welding studies on experimental heats of Alloy 709 in plate form by the ART Program (Yamamoto, 2014) revealed potential issues of weld solidification cracking when the level of impurities such as $\mathrm{P}$ is high but still within the ASME BPVC.II SA-213/SA-213M (ASME, 2021). Only the weldment with very low P content (less than $20 \mathrm{wppm}$, or $0.002 \mathrm{wt} \%$ ) in both the base metal (plate form) and the matching filler metal passed the ASME Section IX weldment qualification test. While a Section IX qualified weldment was fabricated successfully, the requirement of very low P content (20wppm) places a severe restriction.

The objective of this study was to research and develop suitable welding techniques that would successfully weld Alloy 709 base metal with higher P content within the limit of ASME BPVC.II SA213/SA-213M (ASME, 2021), and evaluate the options to relax the tight restriction on P content for the weld wire. To this end, computational solidification simulation modeling was first carried out in 2018 (Feng, Vitek, Liu, \& Wang, 2018) to investigate the solidification behavior of Alloy 709. The roles of alloying elements, in particular the impurity elements $\mathrm{P}, \mathrm{S}$, and B on solidification behavior and susceptibility of weld solidification cracking were systematically analyzed and identified using the computational simulation model. Scheil simulations of non-equilibrium solidification were performed to simulate the solidification during welding. Equilibrium calculations were also made for comparison. It was found that $\mathrm{P}$ has the most important impact on solidification behavior. Increasing levels of $\mathrm{P}$ from $0.002 \mathrm{wt} \%$ (20wppm) to $0.018 \mathrm{wt} \%(180 \mathrm{wppm})$ led to a decrease in the solidus temperature of over 
$300^{\circ} \mathrm{C}$. That is, high levels of $\mathrm{P}$ lead to very large increases in the non-equilibrium solidification temperature range. Thus, $\mathrm{P}$ is expected to significantly increase the susceptibility of weld solidification cracking of Alloy 709. This conclusion was supported by limited experimental data that showed poor weldability and considerable cracking for experimental Alloy 709 heats $(<20 \mathrm{wppm} \mathrm{P})$ when welded with weld wires of high P levels (Yamamoto, 2014)

The knowledge obtained from the computational modeling above leads to the development of strategies to weld Alloy 709 having wide range of chemistries without weld solidification cracking to support code qualification. One of the approaches was to limit the P level of the weld wire when welding Alloy 709 base metal having relatively high $\mathrm{P}$. For weld wires with high $\mathrm{P}$ levels, special welding procedures or innovative welding techniques may be necessary to produce code qualified welds.

In FY 2019 and FY 2020 (Feng et al. 2019, 2020), a series of ASME Section IX qualified welds were successfully fabricated using the low $\mathrm{P}$ weld wire $(<20 \mathrm{wppm} \mathrm{P})$ on the first commercially produced heat - the Carlson Heat 58776 Alloy 709 plates. It is noted that the Carlson heat Alloy 709 plates has relatively high $\mathrm{P}$ level of $140 \mathrm{wppm}$. In addition, through welding parameters optimization, it demonstrated the possibility of welding the Carlson Heat Alloy 709 plates using high $\mathrm{P}$ weld wire (140 wppm P), although welding defects related to solidification cracking within the qualified limit could not be eliminated.

As part of a parallel base metal Alloy 709 R\&D effort on under the ART Program, a heat treatment protocol was developed to enhance the creep-fatigue resistance of Alloy 709 (Zhang, Sham and Young, 2019). Welding of such heat-treated Alloy 709 base metal was the focus in FY2021 welding development effort, and the goal is to confirm the suitability of the previously developed welding procedures to the heat-treated Alloy 709 plates. This report summarizes the welding research progress on heat-treated Carlson heat Alloy 709 plates in FY2021. 


\section{MATERIAL}

The Alloy 709 base metal used in this work was the first commercial heat produced within the U.S. and the hot-rolled plates fabricated from this commercial heat were procured as part of the Alloy 709 fabrication scale up effort by the ART Program. This commercial heat was produced by G.O. Carlson Inc. in Pennsylvania (Carlson Heat 58776). Details of the manufacture process of the Carlson Heat 58776 are provided in a report by (Natesan, Natesan, Zhang, Sham, \& Wang, 2017). The Carlson Heat 58776 was processed by either Argon-Oxygen-Decarburization (AOD) or by additional electroslag remelting (ESR). They were subsequently hot-rolled and solution annealed (SA) at different temperatures. Table 1 lists the base metal plates used in this work. They were all from the master heat, Carlson Heat 58776, subjected to different heat treatment schedules.

In developing Alloy 709 for ASME code qualification, a sub-set of base plates were age heat treated. The aging heat treatment protocol $\left(775^{\circ} \mathrm{C}\right.$ for 10 hours, followed by air cool) was developed to enhance its creep-fatigue resistance (Zhang, Sham, \& Young, 2019). Welding of this heat-treated base metal (ESR1150-AH in Table 1) was the focus of welding research in FY 2021. The welding parameters were built upon the previously developed welding procedure.

Table 1 Heat treatment conditions of base metal plates in this work

\begin{tabular}{|c|c|c|c|c|c|}
\hline $\begin{array}{c}\text { Designated } \\
\text { Base Plate ID }\end{array}$ & $\begin{array}{c}\text { Base Plate } \\
\text { Heat Number }\end{array}$ & Melting & $\begin{array}{c}\text { Solution Heat } \\
\text { Treatment, }{ }^{\circ} \mathrm{C}\end{array}$ & $\begin{array}{c}\text { Aging Heat } \\
\text { Treatment, }\end{array}$ & $\begin{array}{c}\text { Plate thickness, } \\
\mathrm{mm}\end{array}$ \\
\hline ESR1100 & $58776-3 R B B$ & AOD+ESR & 1100 & none & 28.5 \\
\hline ESR1150 & $58776-3 R B C$ & AOD+ESR & 1150 & none & 28.5 \\
\hline ESR1150-AH & ESR1150-AH & AOD+ESR & 1150 & $775^{\circ} \mathrm{C}, 10 \mathrm{~h}$, air cool & 28.5 \\
\hline AOD1050 & $58776-4 \mathrm{~A}$ & AOD only & 1050 & none & 30 \\
\hline AOD1100 & $58776-4 \mathrm{~B}$ & AOD only & 1100 & none & 30 \\
\hline
\end{tabular}

The chemical compositions of the Carlson Heat 58776 base metal plates used in this study are given in Table 2. As shown in the table, the Carlson Heat has relatively high P level at $0.014 \mathrm{wt} \%$ (140wppm). For comparison, Table 2 also provides the specifications for the chemical requirements of Nippon Steel NF709, TP310MoCbN, seamless tubing, with a UNS number of S31025 in ASME SA-213 (ASME 2019a).

Table 2. Chemical compositions of Alloy 709 materials (wt\%).

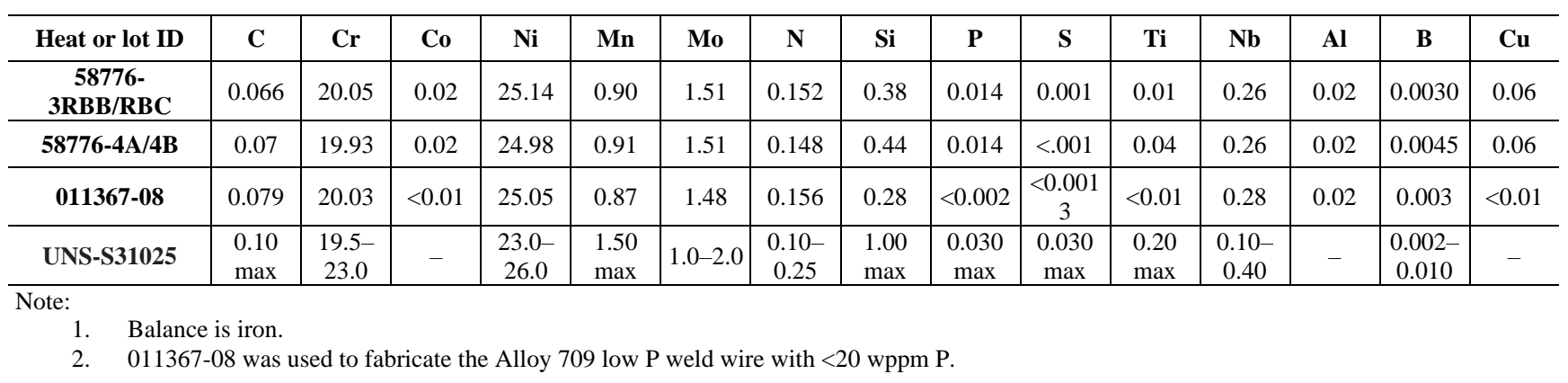

The two Alloy 709 weld wires used in this research were fabricated through wire drawing process from the base metal plates. The weld wire with 140 wppm $\mathrm{P}$ was from the Carlson Heat 58776-4A plate. The weld wire with less than 20 wppm P was produced from a lab heat 011367-08 Alloy 709 plate 
(manufactured by Carpenter Technology Corporation). The chemical compositions of the heat 011367-08 base metal are also listed in Table 2. Both base metal and the weld wires used in this welding research met the specified NF709 chemical requirements.

Room temperature cross-weld tensile tests are required per welding procedure qualifications requirements in ASME Section IX. The tensile specimen geometry and dimensions for Alloy 709 welds are shown in Figure 1. The centerline of the weldment is at the mid-length of the gage section, and the entire weld was within the reduced section of the tensile specimen.

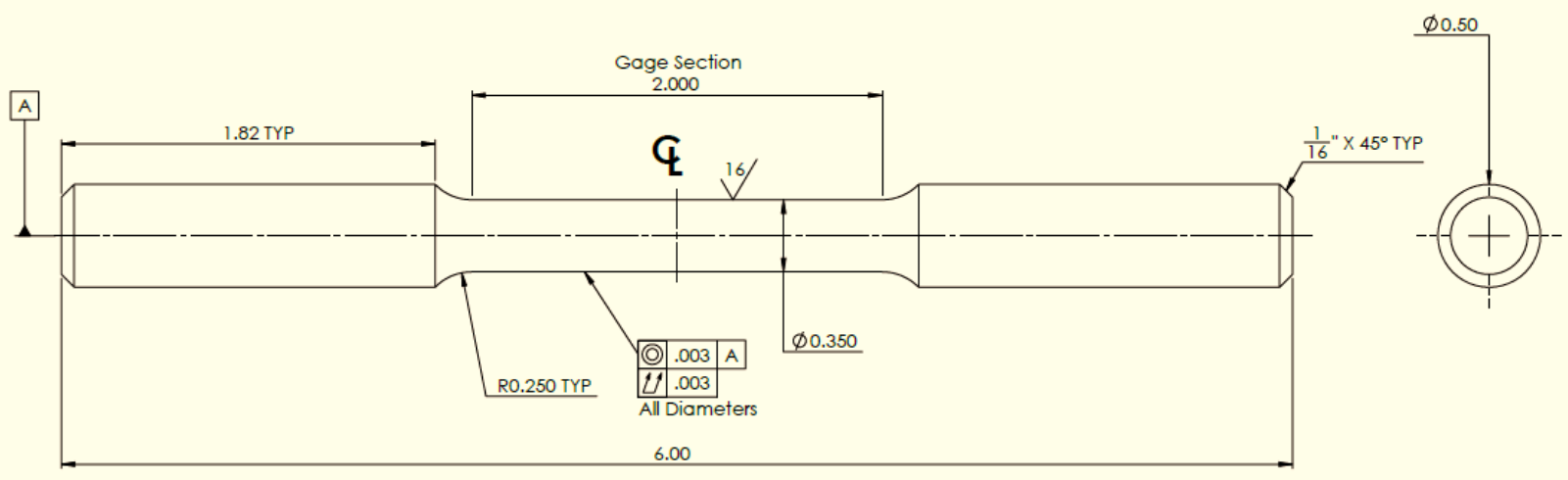

Figure 1. Room temperature cross-weld tensile specimen geometry (dimensions are in inches)

In support of Alloy 709 code qualification, cross-weld creep tests were also planned and performed under this welding research program. The weld creep specimen used the same geometry as the base metal creep specimen, shown in Figure 2. The cross-weld creep specimens are machined to allow the centerline of the weldment at the mid-length of the gage section, and the entire weld was within the reduced section of the tensile specimen.

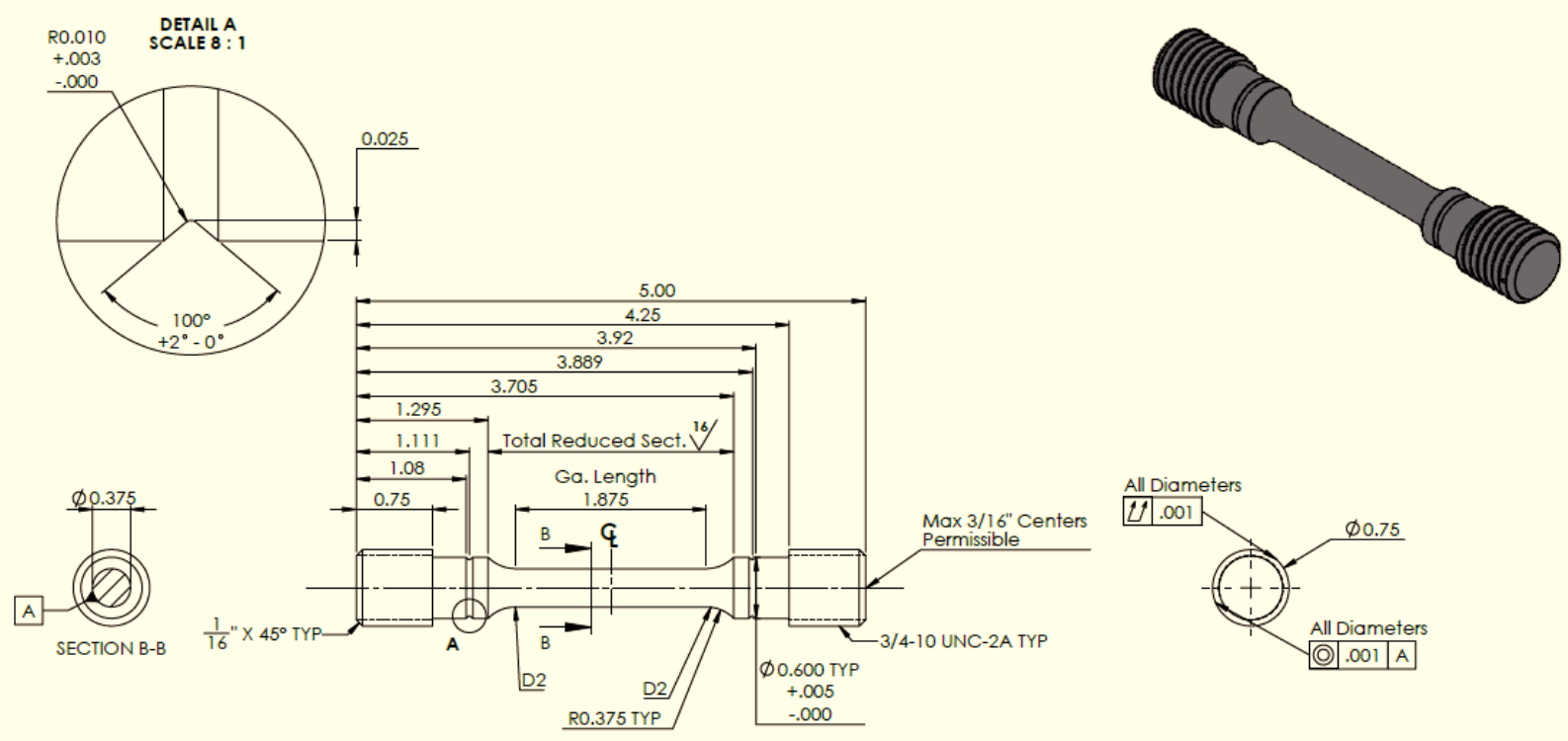

Figure 2. Alloy 709 cross-weld creep specimen geometry (dimensions are in inches) 


\section{WELDING AND WELD QUALIFICATION TEST}

The Alloy 709 base metal plates were butt-welded with single V-groove joint and the details of the joint are shown in Figure 3. Gas tungsten arc welding (GTAW) was used. A total of 9 combinations of base metal and weld wires have been fabricated and tested so far, which is summarized in Table 3. It is noted that the Carlson Heat 58776 base metal plates had relatively high P level at 140wppm. The two weld wires had two different P levels: the low P level at less than $20 \mathrm{wppm}$, and the high P level at 140wppm.

Part of the weld qualification tests and weld microstructure characterization on welds W1-W6 was provided in previous reports by Feng et al, 2019 and Feng et al, 2020. This report provides additional results on the weld qualification test of welds W6, as well as on three new welds, W7, W8 and W10. All these welds, W6, W7, W8 and W10, were fabricated on ESR1150-AH plates. Note that W8 weld had a medium $\mathrm{P}$ level - it was welded using a twin wire technique by twisting the low $\mathrm{P}$ and high $\mathrm{P}$ weld wires $(0.035$ " dia.) together, resulting in an estimated P level of 80wppm.

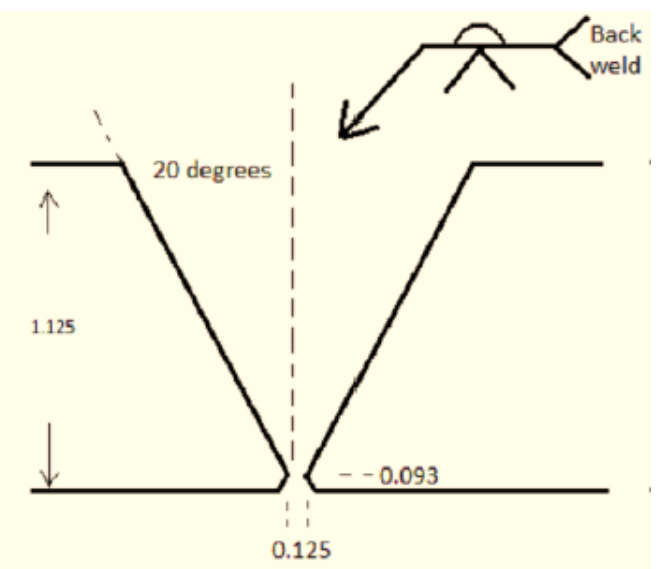

Figure 3. Single V-groove joint preparation details used in the study

Table 3. Combination of weld wire and base metal conditions investigated in this study

\begin{tabular}{|c|c|c|c|c|c|c|c|c|}
\hline \multirow{2}{*}{$\begin{array}{l}\text { Weld } \\
\text { ID }\end{array}$} & \multicolumn{3}{|c|}{ Weld Wire } & \multirow{2}{*}{$\begin{array}{l}\text { Base Metal } \\
\text { Plate ID }\end{array}$} & \multirow{2}{*}{$\begin{array}{c}\text { Base } \\
\text { metal } \\
\text { plate } \\
\text { thickness } \\
(\text { in })\end{array}$} & \multicolumn{3}{|c|}{$\begin{array}{l}\text { ASME Sec. IX Weld } \\
\text { Qualification }\end{array}$} \\
\hline & $\begin{array}{l}\text { P Level } \\
\text { (wppm) }\end{array}$ & $\begin{array}{l}\text { Origin Heat } \\
\text { No. }\end{array}$ & Wire dia. (in) & & & $X-R a y$ & $\begin{array}{l}\text { Side } \\
\text { Bend }\end{array}$ & $\begin{array}{c}R T \\
\text { Tensile }\end{array}$ \\
\hline W1 & $<20($ Low $P)$ & 011367-08 & 0.064 & ESR1100 & 0.79 & Pass & Pass & Pass \\
\hline W2 & $<20($ Low $P)$ & 011367-08 & 0.064 & ESR1100 & 1.12 & Pass & Pass & Pass \\
\hline W3 & 140 (High P) & 58776-4A1 & 0.064 & ESR1100 & 1.12 & Fail & N/A & N/A \\
\hline W4 & 140 (High P) & 58776-4A1 & 0.064 & ESR1100 & 1.12 & Pass & Pass & Fail \\
\hline W5 & 140 (High P) & 58776-4A1 & 0.045 & ESR1150-AH & 1.12 & Pass & Pass & Pass \\
\hline W6 & $<20($ Low $\mathrm{P})$ & 011367-08 & 0.035 & ESR1150-AH & 1.12 & Pass & Pass & Pass \\
\hline W7 & 140 (High P) & 58776-4A1 & 0.035 & ESR1150-AH & 1.12 & Pass & Pass & Pass \\
\hline W8 & $\begin{array}{l}\text { Approx. } \\
\text { 80wppm } \\
\text { (Med P) }\end{array}$ & $\begin{array}{l}011367-08 / \\
58776-4 \mathrm{~A} 1\end{array}$ & $\begin{array}{l}\text { twin wires } \\
0.035+0.035\end{array}$ & ESR1150-AH & 1.12 & Pass & Pass & Pass \\
\hline $\begin{array}{c}\text { W10 } \\
\text { (Code } \\
\text { Case } \\
\text { Weld) }\end{array}$ & $<20($ Low $\mathrm{P})$ & 011367-08 & 0.035 & ESR1150-AH & 1.12 & Pass & Pass & Pass \\
\hline
\end{tabular}




\subsection{WELD W6}

\subsubsection{Welding (W6)}

The W6 Weld was fabricated on the ESR1150-AH plates using the weld wire with less than 20wppm P level. The detailed welding procedure and the welding parameters were documented in Feng et al., 2020. There was no pre-heating of the base metal plate nor the weld wire, and the inter-pass temperature was kept being below $100^{\circ} \mathrm{C}$. Using a smaller diameter $\left(0.89 \mathrm{~mm} / 0.035^{\prime}\right.$ "dia.) weld wire, the heat input was reduced from those of previous welds fabricated with larger wire diameter of $1.63 \mathrm{~mm}(0.064$ "), which in general is beneficial to mitigate weld solidification cracking problems.

\subsubsection{Qualification test (W6)}

The W6 weld was inspected with X-ray and found acceptable per ASME Section IX with no relevant indications of welding flaws (Feng, et al, 2020). It was further evaluated with side bending tests, metallurgy characterization, tensile tests, and creep tests. Specimens for testing were taken from the welded plate according to Figure 4 . The results from three duplicate side bend tests showed no indications of any cracks in the weldment (Feng, et al, 2020).

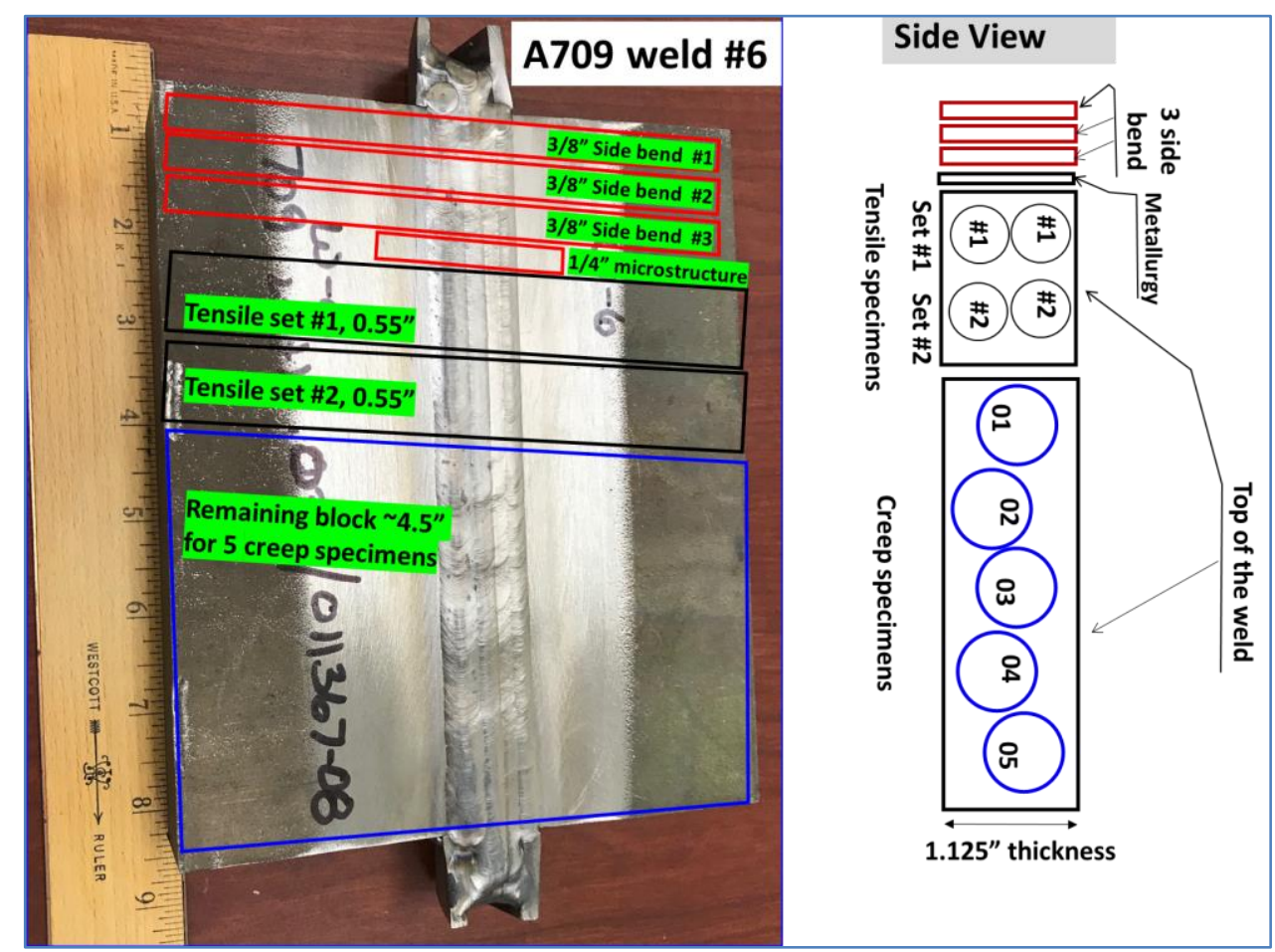

Figure 4. Sectioning diagram of W6 Weld.

Two sets of cross-weld tensile test specimens were machined from Weld W6. Each set of the tensile tests had one specimen out of the top of the weld and one out of the bottom of the weld. The room temperature tensile stress-strain curves are plotted in Figure 5. The tensile strengths of the four test specimens are summarized in Table 4. The tensile strengths of all four specimens were above the minimum ASME code required base metal tensile strength of 640MPa. For both sets of the tensile tests, the bottom of the weld consistently showed higher tensile strength than the top of the weld. 
A photograph of the cross-weld specimens from 709 weld W6 after room temperature tensile testing is shown in Figure 6. The center of the weldment was marked with an arrow. One of the tensile specimens from the bottom of the weld failed in the base metal, i.e., outside the entire weldment. The failure location of the remaining three tensile specimens was inside the weldment. All four tensile specimens showed ductile failure mode. As such, Weld W6 passed the ASME Section IX weld quality requirement test.

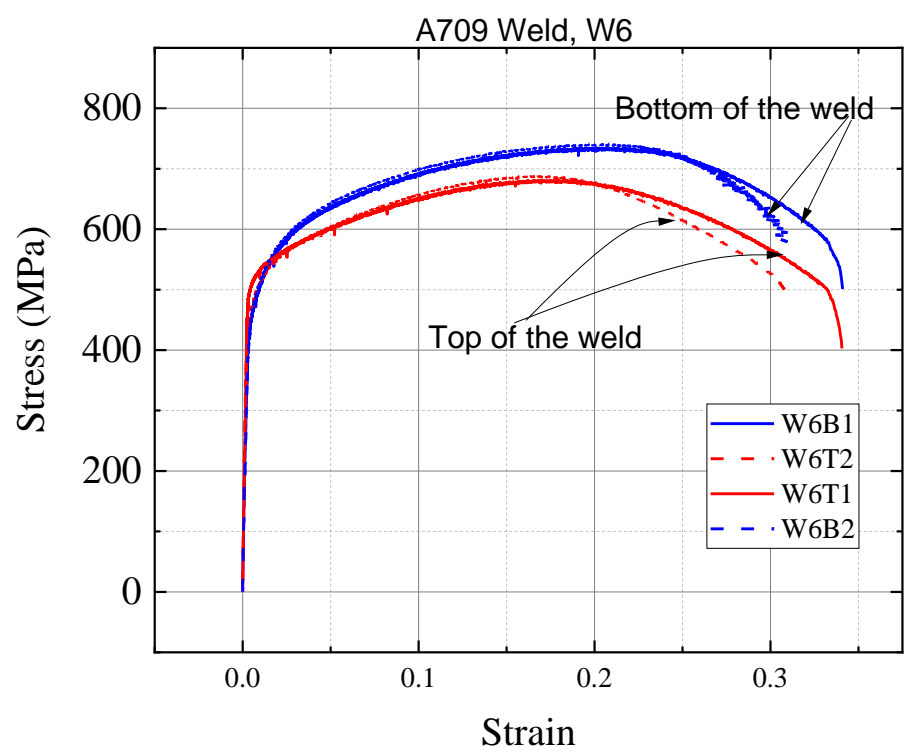

Figure 5. Room temperature cross-weld tensile results for Weld W6

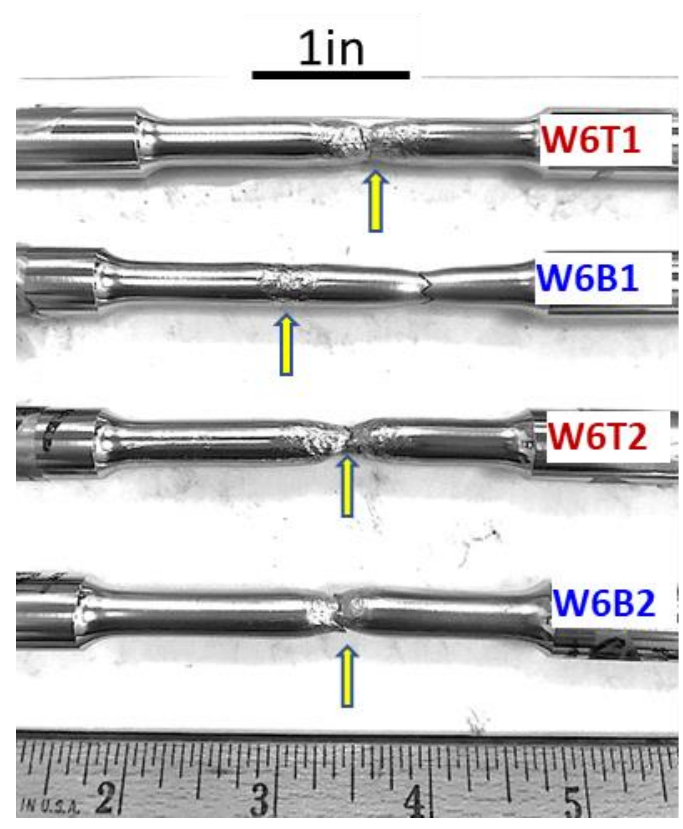

Figure 6. Photograph of the room temperature cross-weld tensile test results from Weld W6 
Table 4. Room temperature cross-weld tensile results for Weld W6

\begin{tabular}{l|l|l}
\hline & Location of the tensile specimens & $\begin{array}{l}\text { Tensile strength, } \\
\text { MPa }\end{array}$ \\
\hline \multirow{2}{*}{$\begin{array}{l}\text { Cross-weld tensile } \\
\text { test set \#1 }\end{array}$} & Top of the weld & 681.5 \\
\cline { 2 - 3 } $\begin{array}{l}\text { Cross-weld tensile } \\
\text { test set \#2 }\end{array}$ & Bottom of the weld & 734.7 \\
\cline { 2 - 3 } & Top of the weld & 689.0 \\
\hline
\end{tabular}

\subsubsection{Microstructure characterization (W6)}

Figure 7 shows the optical image of the cross-section of the W6 weld. There was no visible weld defects and cracks in the entire weld.

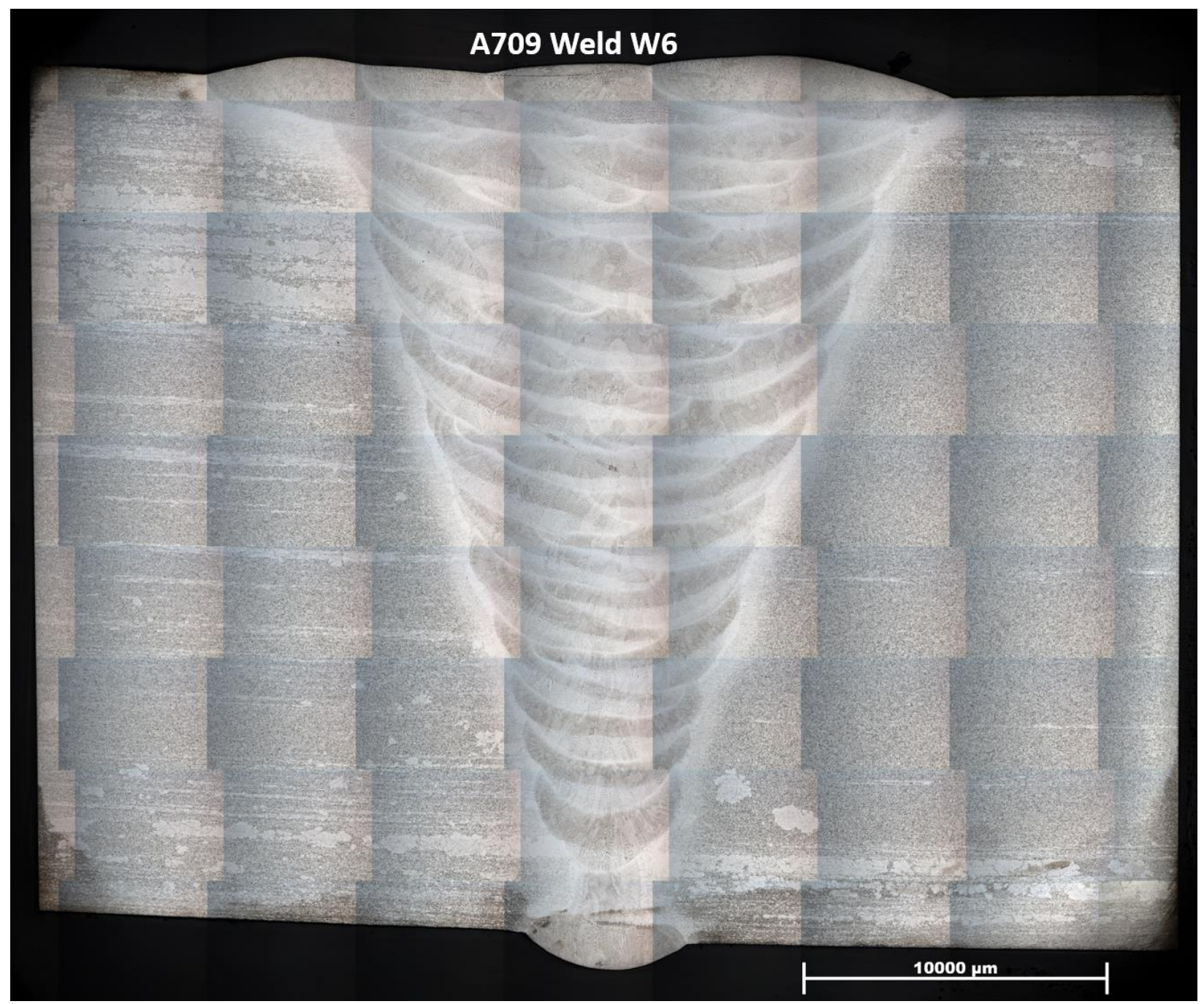

Figure 7. Cross-section view of Weld W6. No apparent weld defect or cracking were observed. 


\subsection{WELD W7}

Previously, Welds W3 and W4 fabricated with 140wppm P weld wire on the Carlson Heat (ESR 587763RBB) did not pass the ASME Section IX weld qualification test (Feng, Wang, Kyle, \& Dai, 2019). W3 showed severe indications of weld defects under X-ray NDE, thus no further qualification tests were carried out. Weld W4 passed the X-ray inspection and side bending test. However, it did not pass the room temperature tensile tests, and sub-mm sized cracks were found in the weld, predominately around the weld centerline associated with the final weld passes. Detailed EPMA micro-chemistry analysis confirmed significant micro-segregation of $\mathrm{P}$ at the interface of solidification dendritic sub-grains and grain boundaries. It is noted that no noticeable macro-level, pass-to-pass variations were observed, and some meso-level variations within a weld pass. On the other hand, micro level P segregation of the solidification sub-grain dendrites and grains were extensive. The level of micro-segregation could reach $1460 \mathrm{wppm}$, that is, an order of magnitude higher than the nominal 140wppm P level in the weld metal. The EPMA analysis also showed minimal segregation in the base metal and HAZ, as expected. The average $\mathrm{P}$ in the weld and base metal was consistent with the chemistry analysis of the P level 140wppm.

Subsequently, the welding heat input was reduced in making Weld W5, for the 140wppm P weld wire. The reduction of heat input was accomplished by reducing the weld wire diameter from $1.626 \mathrm{~mm}$ (0.064") to $1.143 \mathrm{~mm}(0.045 ")$, and by using hot-wire GTAW. Weld W5 successfully passed all the qualification tests including X-ray inspection, side bend and room temperature tensile (Feng et al, 2020). However, hot-wire welding was rather restrictive. In this report period, Alloy 709 weld, W7, was fabricated without using the hot-wire, to evaluate the feasibility of achieving a code qualified weld with 140wppm weld wire only through using smaller gage weld wire. For Weld W7, the 140wppm P weld wire was 0.035 " in diameter, which allowed further reducing the welding heat input from $25-30 \mathrm{~kJ} / \mathrm{in}$ in $\mathrm{W} 5$, to $20 \mathrm{~kJ} / \mathrm{in}$ as shown in Table 5 .

\subsubsection{Welding of $\mathrm{W} 7$ with high $P$ weld wire}

The basic weld joint configuration (single V groove butt weld) used for Weld W7 was the same as all previous welds (Figure 3). The actual weld-pass layout for Weld W7 weld is schematically shown in Figure 8. There was a total of 36 welding passes. Same as previous welds, there was no pre-heating and the inter-pass temperature was kept below $100^{\circ} \mathrm{C}$. The welding parameters of $\mathrm{W} 7$ are shown in Table 5. The average heat input for W7 is similar to that of W6. For Weld W7, the dimension of the base metal plates was $203 \mathrm{~mm}$ (8in) long, $89 \mathrm{~mm}$ (3.5in) wide and $28.5 \mathrm{~mm}$ (1.125in) thick. The total length of the weld was $203 \mathrm{~mm}(8 \mathrm{in})$. 


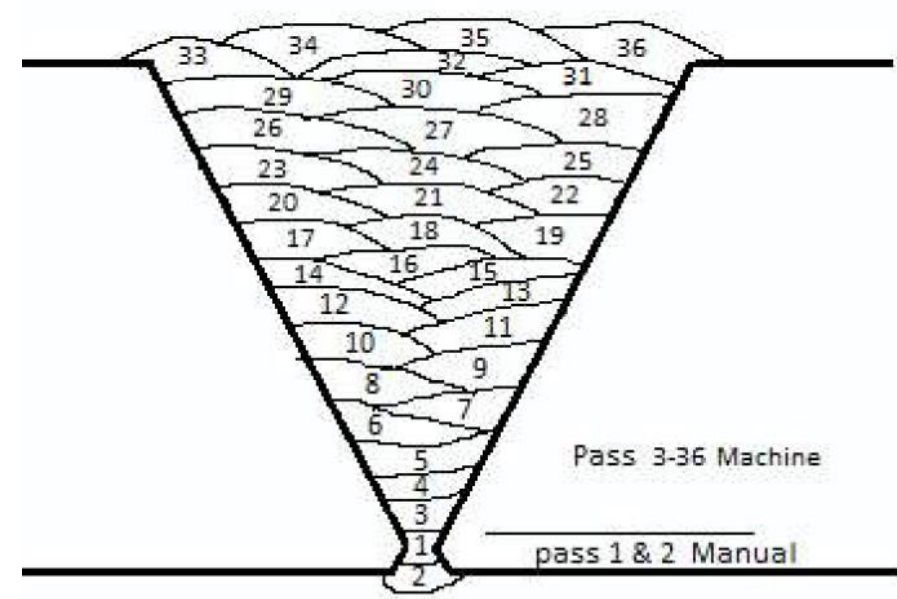

Figure 8. Actual weld-pass layout of Weld W7

Table 5. Welding parameters for Weld W7 (with 140wppm P weld wire)

\begin{tabular}{|c|c|c|c|c|c|c|c|c|c|c|}
\hline Weld/pass & welding process & $\begin{array}{l}\text { preheat interpass } \\
\text { temp degrees C }\end{array}$ & Volts (V) max & Amps (A) & $\begin{array}{l}\text { Travel speed } \\
\text { (ipm) }\end{array}$ & $\begin{array}{c}\text { ASME IX QW 409.1 (a) } \\
\text { Joules/inch }= \\
\text { (Voltage* Amps*60) } /(\text { ipm) }\end{array}$ & $\mathrm{kJ} /$ inch & $\begin{array}{l}\text { Wire feed speed } \\
\text { (ipm) automatic or } \\
\text { machine only }\end{array}$ & $\begin{array}{l}\text { string or weave, } \\
\text { weave enter } \\
\text { amplitude }\end{array}$ & notes \\
\hline 1 & GTAW Manual & N/A (23 C ambient) & 8.8 & 80 & 2.5 & 16896.0 & 16.9 & N/A & stringer & $\begin{array}{l}.035 \text { wires twisted together. backing weld } \\
\text { pass } 1,100 \text { Argon at } 35 \text { CFH and backing gas }\end{array}$ \\
\hline 2 & GTAW Manual & $<100 \mathrm{C}$ & 10.1 & 95 & 3.0 & 19190.0 & 19.2 & N/A & stringer & $\begin{array}{l}.035 \text { wires twisted together. backing weld } \\
\text { pass 2, } 100 \text { Argon at } 35 \mathrm{CFH} \text { and backing gas }\end{array}$ \\
\hline 3 & GTAW Machine & $<100 \mathrm{C}$ & 10.2 & 165 & 5.0 & 20196.0 & 20.2 & 40 & Stringer & $\begin{array}{l}100 \text { Argon at } 35 \text { CFH and backing gas back } \\
\text { grind pass } 1 \text { then weld }\end{array}$ \\
\hline 4 & GTAW Machine & $<100 \mathrm{C}$ & 10.5 & 175 & 5.5 & 20045.5 & 20.0 & 60 & Stringer & 100 Argon at $35 \mathrm{CFH}$ \\
\hline 5 & GTAW Machine & $<100 \mathrm{C}$ & 9.8 & 170 & 5.0 & 19992.0 & 20.0 & 65 & Stringer & 100 Argon at $35 \mathrm{CFH}$ \\
\hline 6 & GTAW Machine & $<100 \mathrm{C}$ & 10 & 170 & 5.0 & 20400.0 & 20.4 & 65 & Stringer & 100 Argon at $35 \mathrm{CFH}$ \\
\hline 7 & GTAW Machine & $<100 \mathrm{C}$ & 10 & 170 & 5.0 & 20400.0 & 20.4 & 60 & Stringer & 100 Argon at $35 \mathrm{CFH}$ \\
\hline 8 & GTAW Machine & $<100 \mathrm{C}$ & 10 & 170 & 5.0 & 20400.0 & 20.4 & 65 & Stringer & 100 Argon at $35 \mathrm{CFH}$ \\
\hline 9 & GTAW Machine & $<100 \mathrm{C}$ & 10.2 & 170 & 5.0 & 20808.0 & 20.8 & 65 & Stringer & 100 Argon at $35 \mathrm{CFH}$ \\
\hline 10 & GTAW Machine & $<100 \mathrm{C}$ & 10.2 & 170 & 5.0 & 20808.0 & 20.8 & 65 & Stringer & 100 Argon at 35 CFH \\
\hline 11 & GTAW Machine & $<100 \mathrm{C}$ & 10.2 & 170 & 5.0 & 20808.0 & 20.8 & 65 & Stringer & 100 Argon at $35 \mathrm{CFH}$ \\
\hline 12 & GTAW Machine & $<100 \mathrm{C}$ & 10.2 & 170 & 5.0 & 20808.0 & 20.8 & 65 & Stringer & 100 Argon at 35 CFH \\
\hline 13 & GTAW Machine & $<100 \mathrm{C}$ & 10.2 & 170 & 5.0 & 20808.0 & 20.8 & 65 & Stringer & 100 Argon at 35 CFH \\
\hline 14 & GTAW Machine & $<100 \mathrm{C}$ & 10.2 & 170 & 5.0 & 20808.0 & 20.8 & 65 & Stringer & 100 Argon at $35 \mathrm{CFH}$ \\
\hline 15 & GTAW Machine & $<100 \mathrm{C}$ & 10.2 & 170 & 5.0 & 20808.0 & 20.8 & 65 & Stringer & 100 Argon at 35 CFH \\
\hline 16 & GTAW Machine & $<100 \mathrm{C}$ & 10 & 170 & 5.0 & 20400.0 & 20.4 & 65 & Stringer & 100 Argon at 35 CFH \\
\hline 17 & GTAW Machine & $<100 \mathrm{C}$ & 10 & 170 & 5.0 & 20400.0 & 20.4 & 65 & Stringer & 100 Argon at $35 \mathrm{CFH}$ \\
\hline 18 & GTAW Machine & $<100 \mathrm{C}$ & 10 & 170 & 5.0 & 20400.0 & 20.4 & 65 & Stringer & 100 Argon at $35 \mathrm{CFH}$ \\
\hline 19 & GTAW Machine & $<100 \mathrm{C}$ & 10 & 170 & 5.0 & 20400.0 & 20.4 & 65 & Stringer & 100 Argon at 35 CFH \\
\hline 20 & GTAW Machine & $<100 \mathrm{C}$ & 10 & 170 & 5.0 & 20400.0 & 20.4 & 65 & Stringer & 100 Argon at $35 \mathrm{CFH}$ \\
\hline 21 & GTAW Machine & $<100 \mathrm{C}$ & 10 & 170 & 5.0 & 20400.0 & 20.4 & 65 & Stringer & 100 Argon at $35 \mathrm{CFH}$ \\
\hline 22 & GTAW Machine & $<100 \mathrm{C}$ & 10 & 170 & 5.0 & 20400.0 & 20.4 & 65 & Stringer & 100 Argon at $35 \mathrm{CFH}$ \\
\hline 23 & GTAW Machine & $<100 \mathrm{C}$ & 10.2 & 170 & 5.0 & 20808.0 & 20.8 & 65 & Stringer & 100 Argon at $35 \mathrm{CFH}$ \\
\hline 24 & GTAW Machine & $<100 \mathrm{C}$ & 10.2 & 170 & 5.0 & 20808.0 & 20.8 & 65 & Stringer & 100 Argon at $35 \mathrm{CFH}$ \\
\hline 25 & GTAW Machine & $<100 \mathrm{C}$ & 10.2 & 170 & 5.0 & 20808.0 & 20.8 & 65 & Stringer & 100 Argon at 35 CFH \\
\hline 26 & GTAW Machine & $<100 \mathrm{C}$ & 10.2 & 170 & 5.0 & 20808.0 & 20.8 & 65 & Stringer & 100 Argon at 35 CFH \\
\hline 27 & GTAW Machine & $<100 \mathrm{C}$ & 10.2 & 170 & 5.0 & 20808.0 & 20.8 & 65 & Stringer & 100 Argon at $35 \mathrm{CFH}$ \\
\hline 28 & GTAW Machine & $<100 \mathrm{C}$ & 10.2 & 170 & 5.0 & 20808.0 & 20.8 & 65 & Stringer & 100 Argon at $35 \mathrm{CFH}$ \\
\hline 29 & GTAW Machine & $<100 \mathrm{C}$ & 10.2 & 170 & 5.0 & 20808.0 & 20.8 & 65 & Stringer & 100 Argon at 35 CFH \\
\hline 30 & GTAW Machine & $<100 \mathrm{C}$ & 10.2 & 170 & 5.0 & 20808.0 & 20.8 & 65 & Stringer & 100 Argon at $35 \mathrm{CFH}$ \\
\hline 31 & GTAW Machine & $<100 \mathrm{C}$ & 10.2 & 170 & 5.0 & 20808.0 & 20.8 & 65 & Stringer & 100 Argon at 35 CFH \\
\hline 32 & GTAW Machine & $<100 \mathrm{C}$ & 10.2 & 170 & 5.0 & 20808.0 & 20.8 & 65 & Stringer & 100 Argon at 35 CFH \\
\hline 33 & GTAW Machine & $<100 \mathrm{C}$ & 10.4 & 165 & 5.0 & 20592.0 & 20.6 & 60 & Stringer & 100 Argon at $35 \mathrm{CFH}$ \\
\hline 34 & GTAW Machine & $<100 \mathrm{C}$ & 10.2 & 165 & 5.0 & 20196.0 & 20.2 & 60 & Stringer & 100 Argon at $35 \mathrm{CFH}$ \\
\hline 35 & GTAW Machine & $<100 \mathrm{C}$ & 10.2 & 165 & 5.0 & 20196.0 & 20.2 & 60 & Stringer & 101 Argon at $35 \mathrm{CFH}$ \\
\hline 36 & GTAW Machine & $<100 \mathrm{C}$ & 10.2 & 165 & 5.0 & 20196.0 & 20.2 & 60 & Stringer & 102 Argon at 35 CFH \\
\hline
\end{tabular}




\subsubsection{Code qualification test of Weld W7}

The baseline weld qualification testing included X-ray inspection, side bend and room temperature crossweld tensile per ASME Section IX. X-ray inspection result performed on W7 is shown in Figure 9. The weld was found to be acceptable with no relevant indication of welding defects.

Test specimens for side bend, room temperature tensile, high temperature creep and microstructure analysis were machined per the layout in Figure 10. The three side bend specimens had 9.53mm (3/8 in) in thickness, and a photograph of the specimens after side bend testing are shown in Figure 11. Small cracks were noticed inside the fusion zone, but the size of the cracks was less than $3 \mathrm{~mm}$, which is acceptable per ASME Section IX code requirement.

Two sets of cross-weld tensile test specimens were machined from Weld W7. The locations of the tensile specimens relative to the welded plate are shown in Figure 10. Similar to the tensile tests of previous welds, each set of the tensile tests had one specimen out of the top of the weld and one out of the bottom of the weld. The room temperature tensile stress-strain curves are plotted in Figure 12. The tensile strengths of the four test specimens are summarized in Table 6 . The tensile strengths of all four specimens were above the minimum ASME code required base metal tensile strength of $640 \mathrm{MPa}$. For both sets of the tensile tests, the bottom of the weld consistently showed higher tensile strength than the top of the weld. It is noticed that one of the tensile specimens from the top of the weld showed much lower elongation and tensile strength, it is suspected that there were welding defects in this specimen which adversely affected the tensile properties.

A photograph of the cross-weld specimens from 709 weld W7 after room temperature tensile testing is shown in Figure 13. The center of the weldment was marked with an arrow. The failure location of all four tensile specimens was inside the weldment. All four tensile specimens showed ductile failure mode. Thus, Weld W7 passed the ASME Section IX weld quality requirement test.

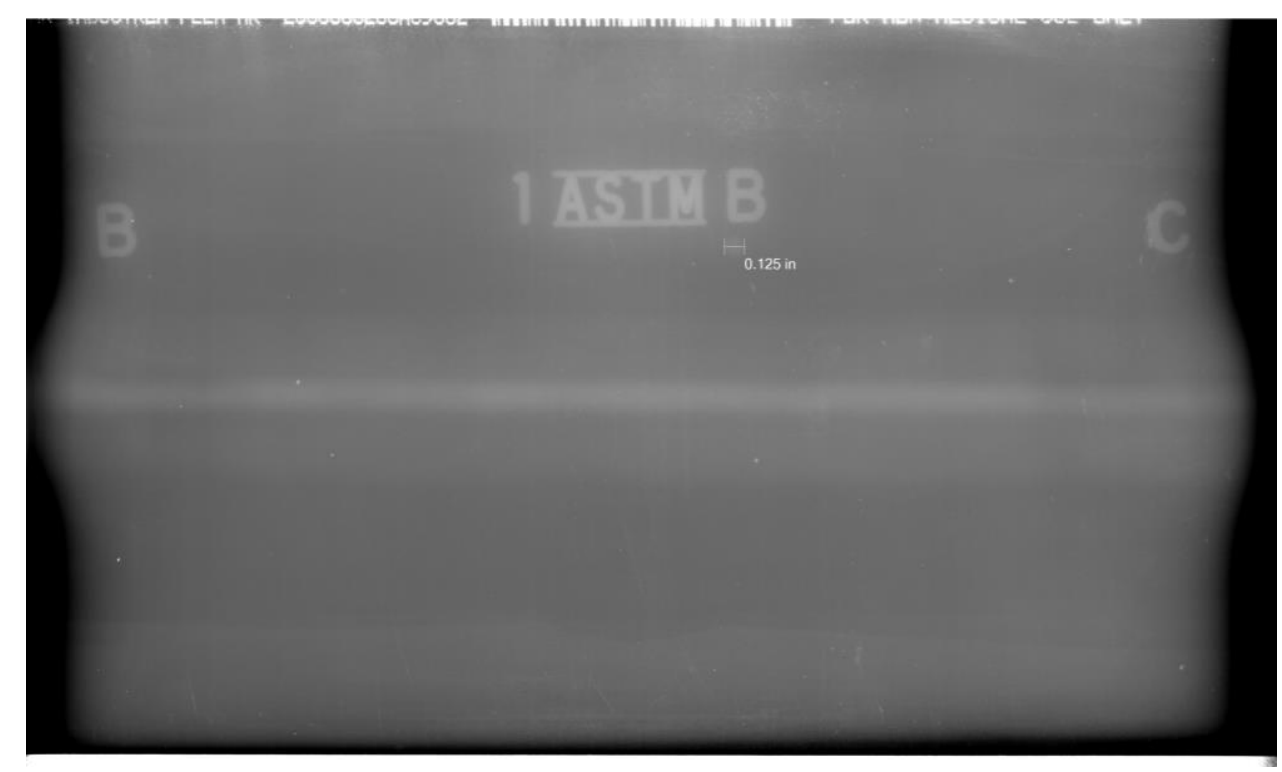

Figure 9. X-ray inspection result of Weld W7 

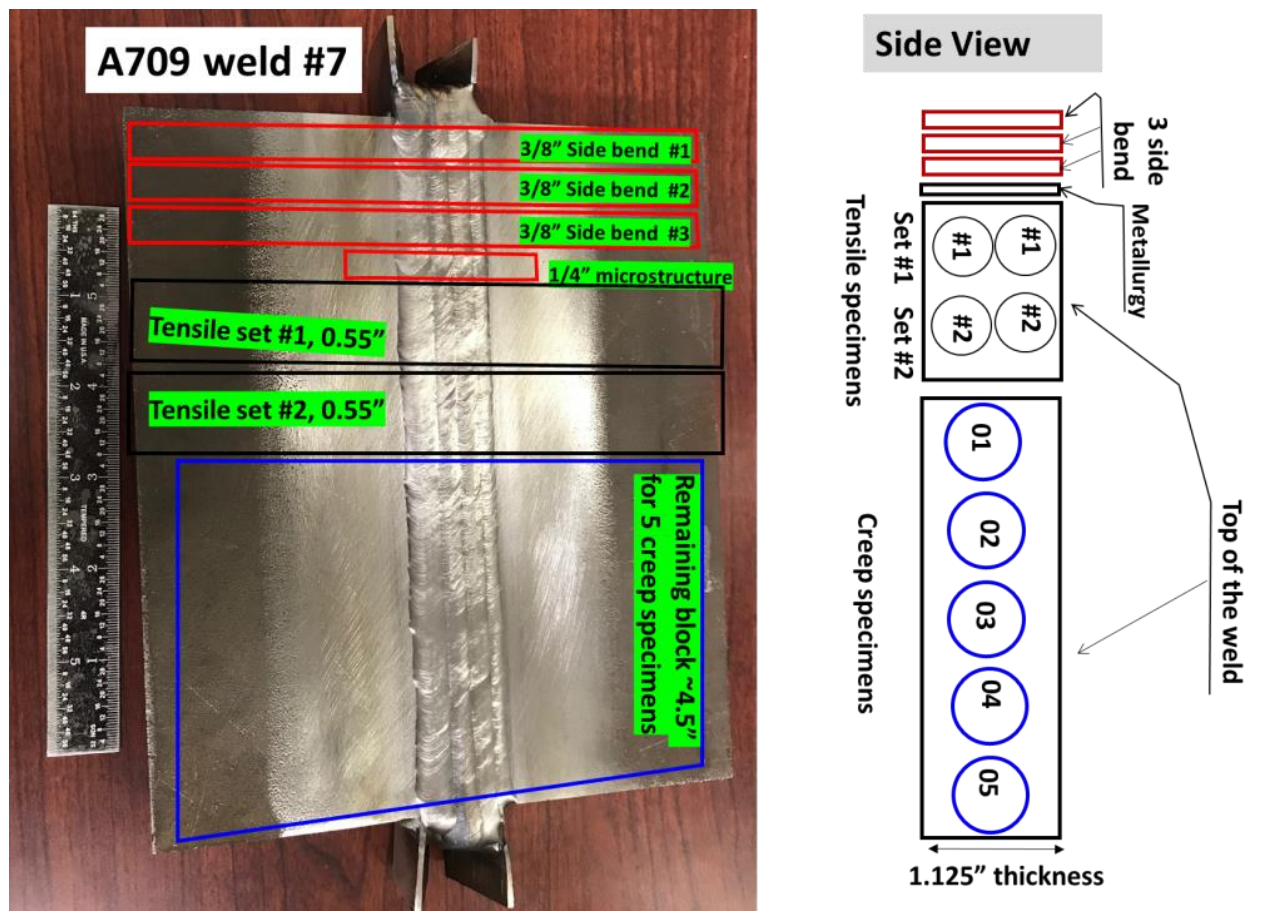

Figure 10.Sectioning diagram of Weld W7.

\section{A709 Weld W7}

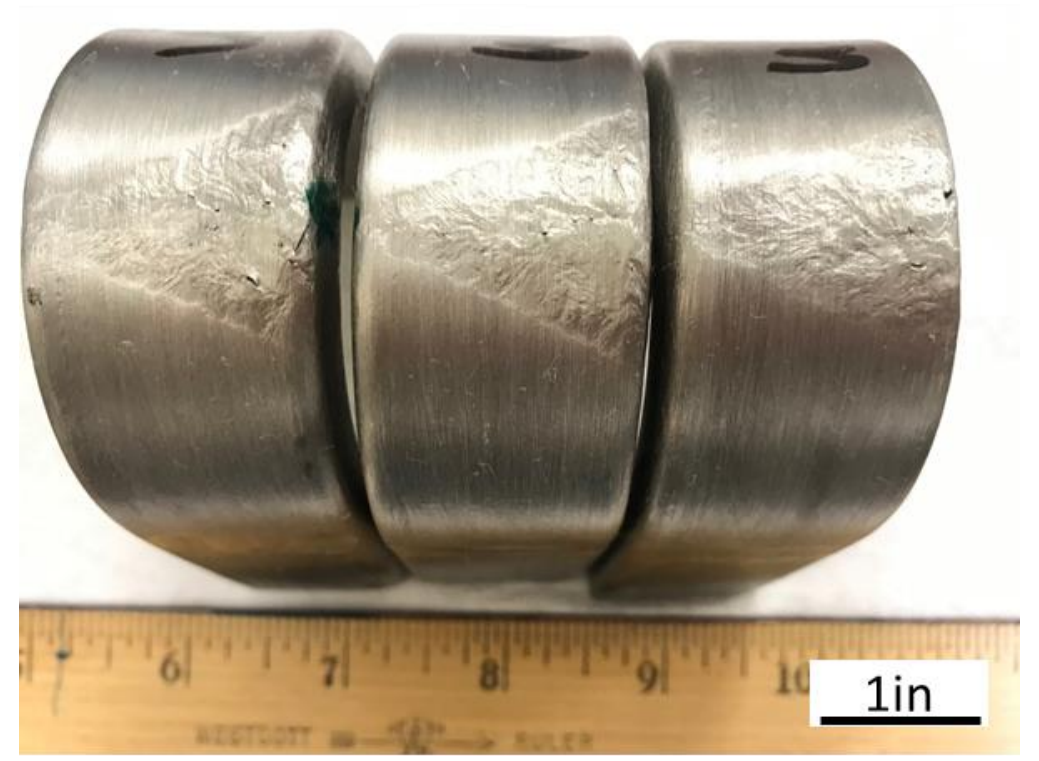

Figure 11. Side bend test results of Weld W7 


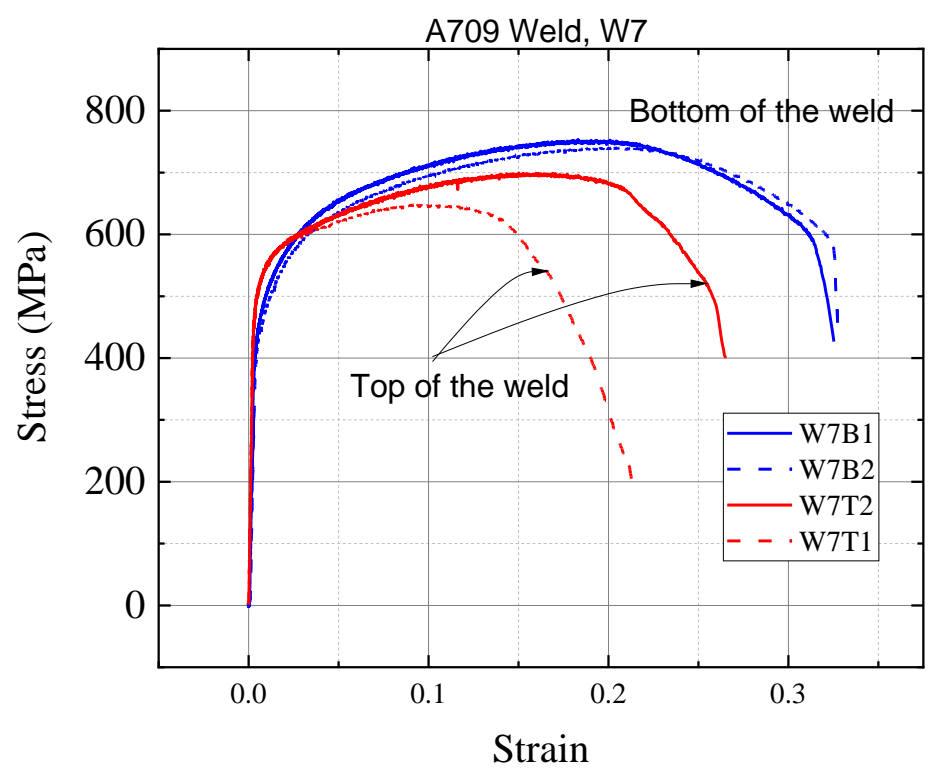

Figure 12. Room temperature cross-weld tensile results for Weld W7
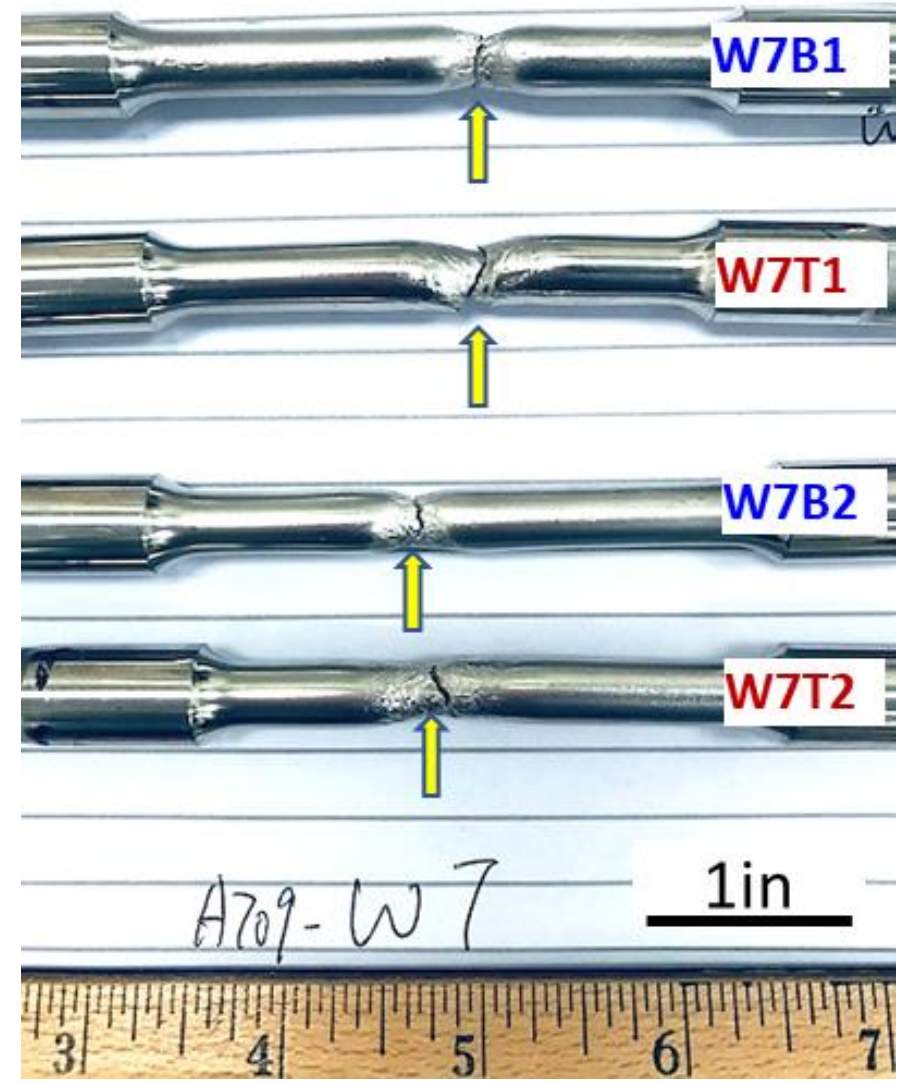

Figure 13. Photograph of the room temperature cross-weld tensile specimens from Weld W7 
Table 6. Room temperature cross-weld tensile results for Weld W7

\begin{tabular}{l|l|l}
\hline & Location of the tensile specimens & $\begin{array}{l}\text { Tensile strength, } \\
\text { MPa }\end{array}$ \\
\hline \multirow{2}{*}{$\begin{array}{l}\text { Cross-weld tensile } \\
\text { test set \#1 }\end{array}$} & Top of the weld & 649.2 \\
\cline { 2 - 3 } Cross-weld tensile & Bottom of the weld & 753.2 \\
\cline { 2 - 3 } test set \#2 & Top of the weld & 699.3 \\
\hline
\end{tabular}

\subsubsection{Microstructure characterization (W7)}

Figure 14 shows the optical image of the weld cross-section of the W7 weld. Micro-fissure type of weld defects were observed, which is consistent with solidification cracking. The maximum size of the cracks is about $500 \mu \mathrm{m}$. These defects are mostly located at the top half of the weld.

Although these weld defects were not detectable under X-ray inspection, they are believed to be the root cause of the adverse tensile properties for the top of the welds.

From previous creep screening tests, the welds exhibited significantly weaker creep strength when multiple relatively large welding defects ( millimeter scale) were present although the weld passed the ASME Section IX qualification tests. The effect of the welding defect on weakening of the creep strength is especially significant when the specimens was tested under higher stresses beyond yield. 


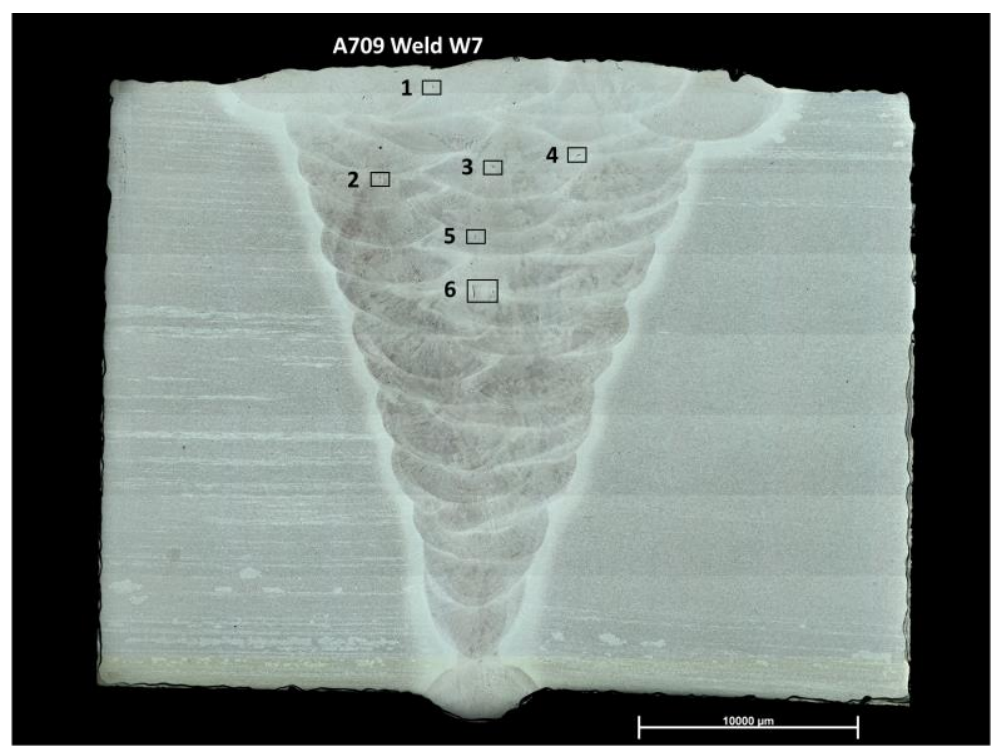

1

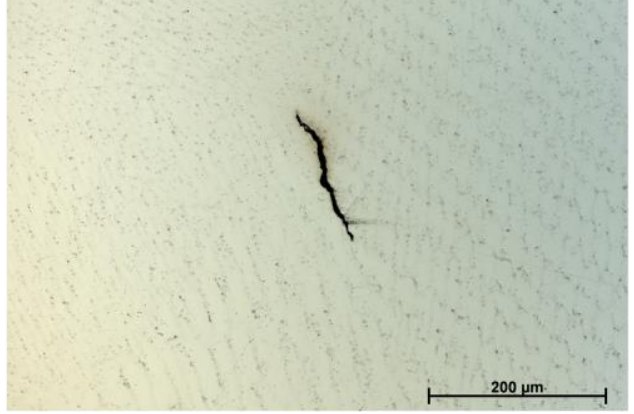

3

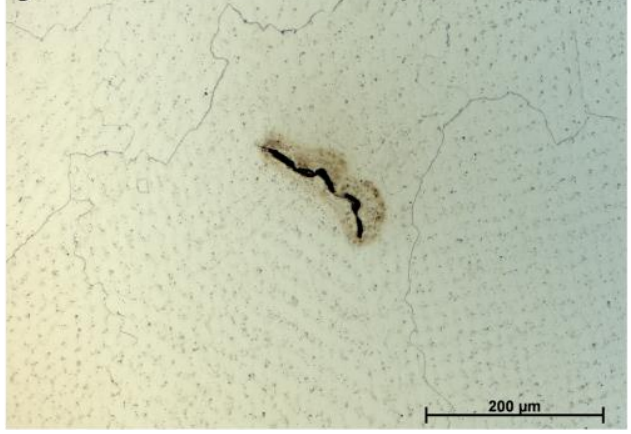

5

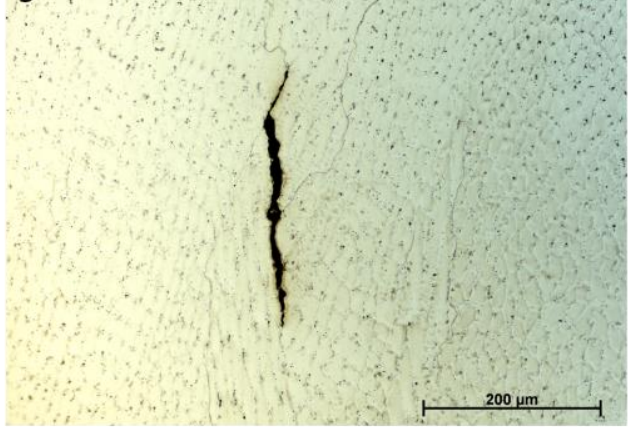

2

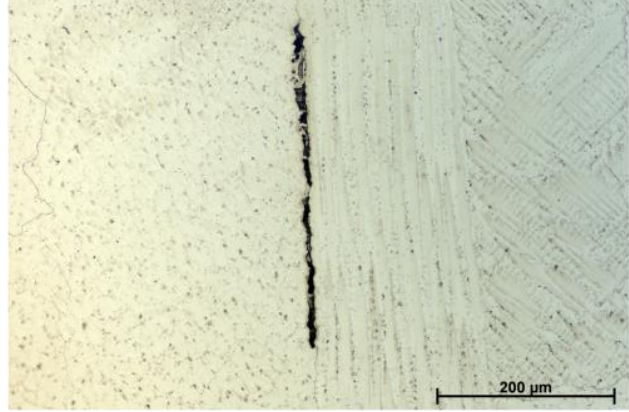

4

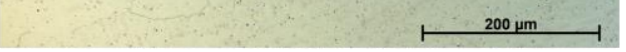

6

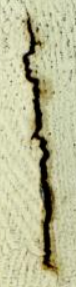

500

Figure 14. Cross-section view and the weld defects observed in Weld W7 


\subsection{WELD W8}

Alloy 709 welding research so far has led to the recommendation of using low P level of weld wire with less than 20wppm for production welds with consistent high quality. However, it is great interest of the Alloy 709 welding development research program to evaluate the possibility of relaxing the tight restriction of the P level. This W8 weld was an attempt for such an evaluation.

\subsubsection{Welding (W8)}

Weld W8 was welded using a twin wire technique by twisting a 20wppm 0.035 " dia weld wire and a 140 wppm 0.035 " dia weld wire together, to create an average P level of approximately $80 \mathrm{wppm}$. The Weld W8 was fabricated with manual GTAW. The total length of the Weld W8 was $203 \mathrm{~mm}(8 \mathrm{in})$, and the thickness of the base metal plates is 1.125 in.

\subsubsection{Qualification test (W8)}

X-ray inspection result performed on W8 is shown in Figure 15. The weld was found to be acceptable with no relevant indication of welding defects. Test specimens for side bend, room temperature tensile, high temperature creep and microstructure analysis were machined per the layout shown in Figure 16. A photograph of the specimens after side bend testing are shown in Figure 17. Small cracks with maximum size of 0.01 " were noticed inside the fusion zone, but the size of the cracks was well within the allowable limit of 0.125 " (or $3 \mathrm{~mm}$ ) per ASME Section IX code requirement, and much smaller than those found in the side bend test samples of W5 and W7 of 140wppm P.

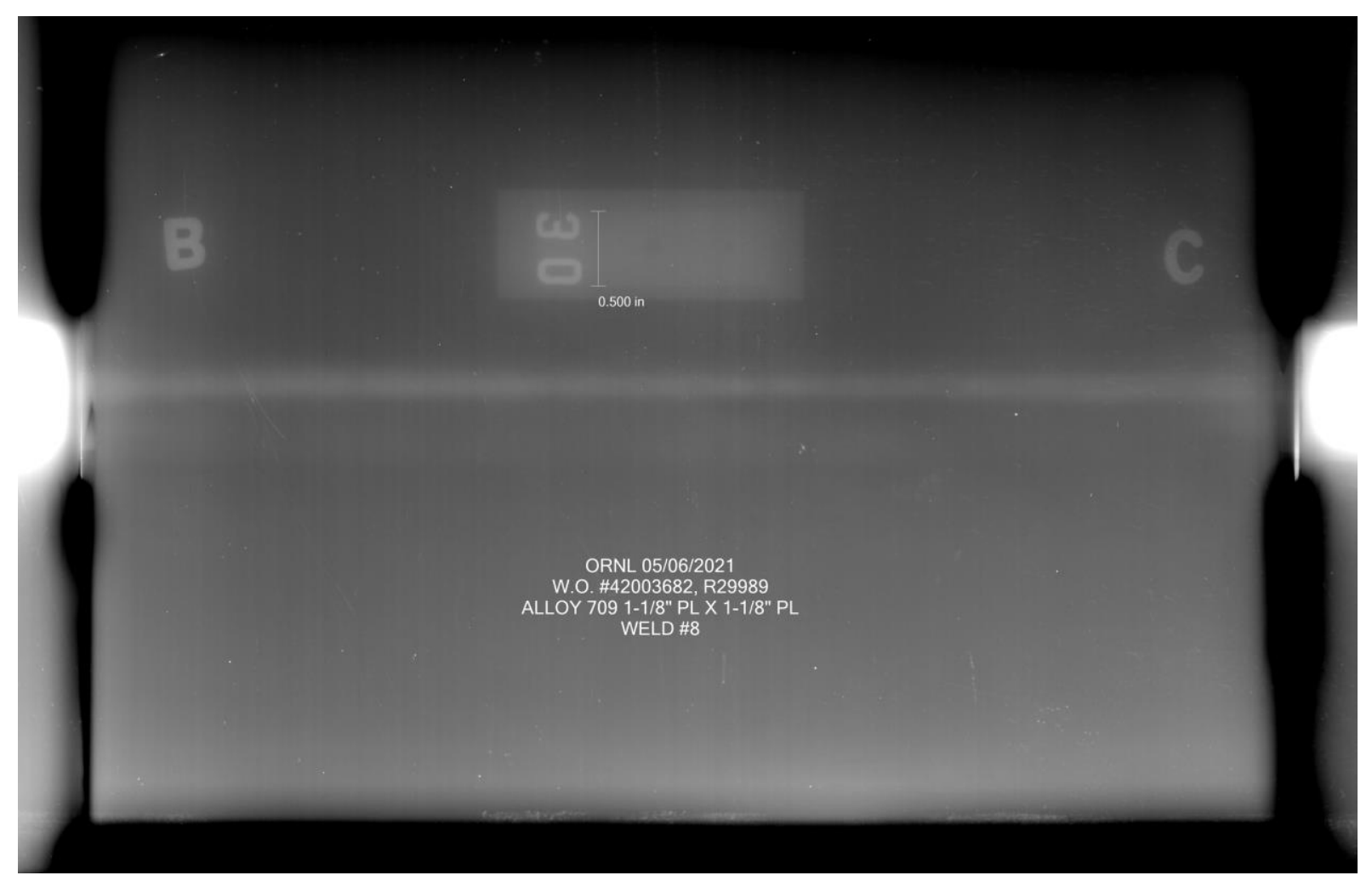

Figure 15. X-ray inspection result of Weld W8 
A709 weld \#8
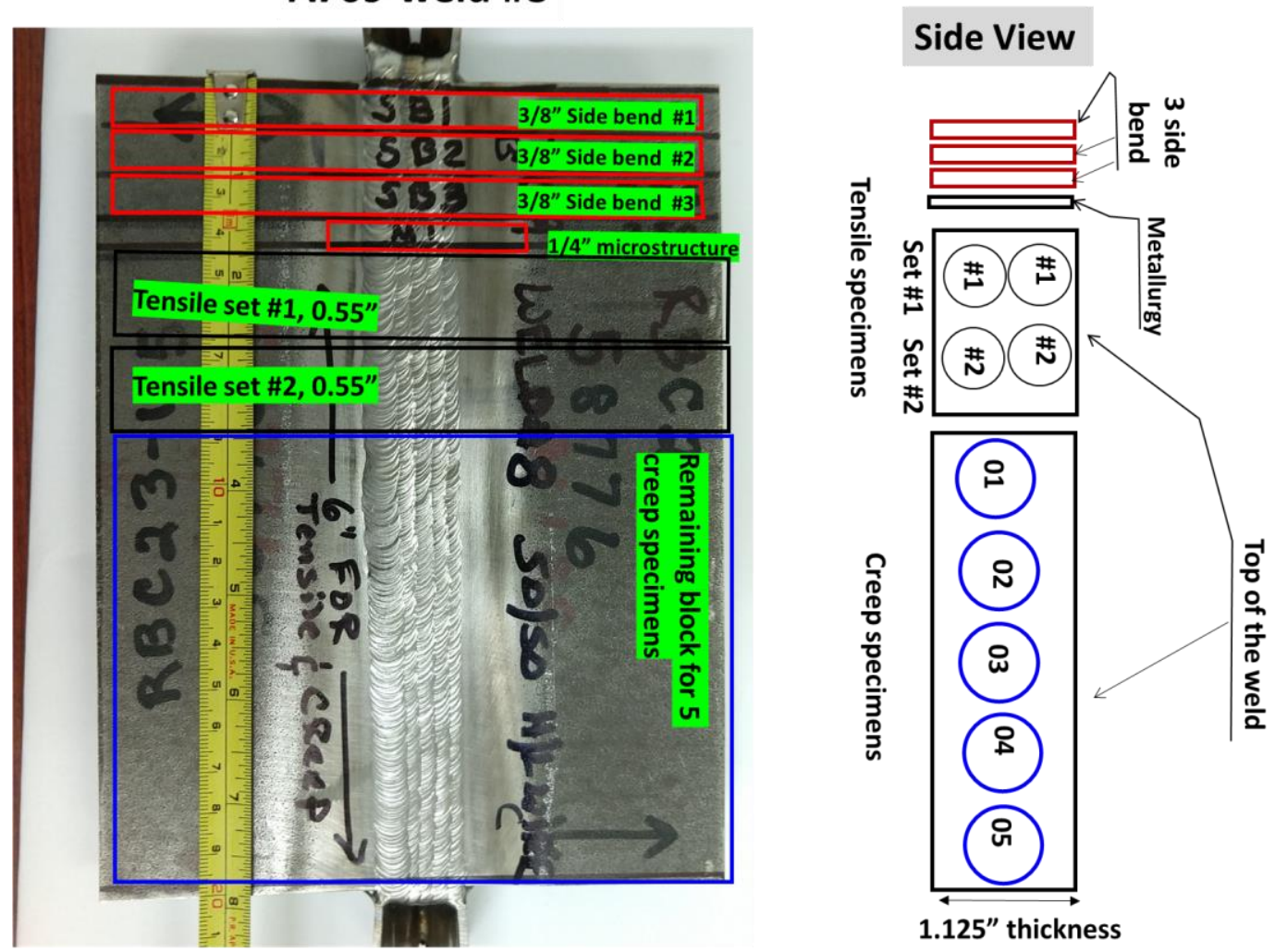

Figure 16. Sectioning diagram of Weld W8

A709 Weld W8

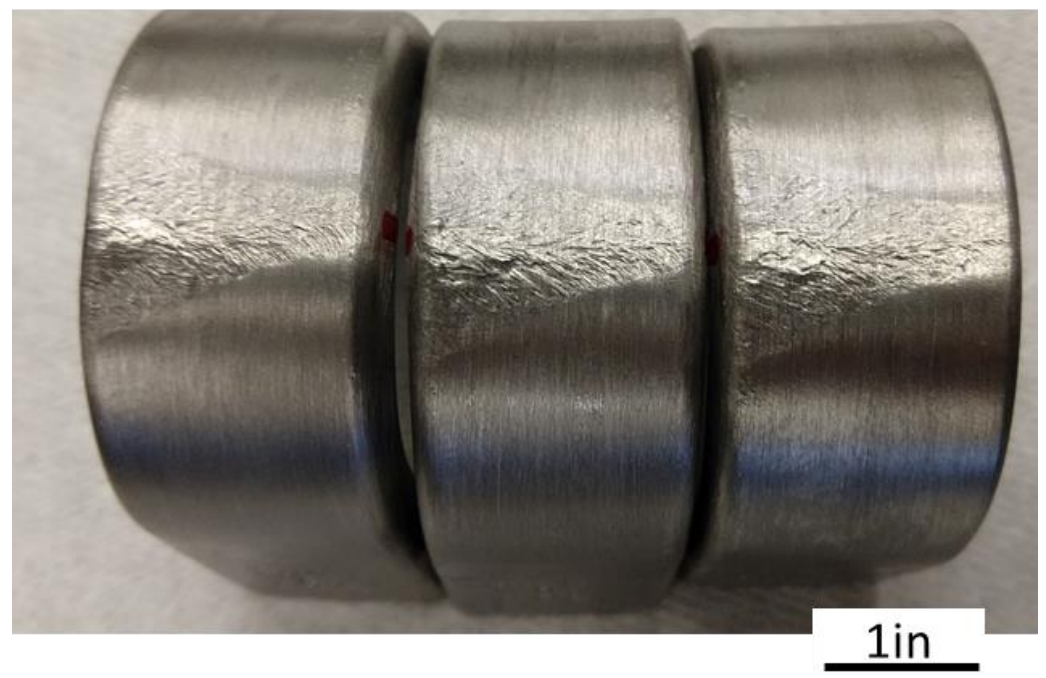

Figure 17. Side bend test results of Weld W8 
Two sets of cross-weld tensile test specimens were machined from Weld W8. Each set of the tensile tests had one specimen out of the top of the weld and one out of the bottom of the weld (Figure 16). The room temperature tensile stress-strain curves are plotted in Figure 18. The tensile strengths of the four test specimens are summarized in Table 7. The tensile strengths of all four specimens were above the minimum ASME code required base metal tensile strength of 640MPa. Similar to previous welds, for both sets of the tensile tests, the bottom of the weld consistently showed higher tensile strength than the top of the weld. A photograph of the cross-weld specimens from 709 weld W8 after room temperature tensile testing is shown in Figure 19. The center of the weldment was marked with an arrow. The failure location of both specimens from the bottom of the welds failed outside the weld, and both tests from the top of the weld failed inside the weldment. All four tensile specimens showed ductile failure mode. Thus, Weld W8 passed the ASME Section IX weld quality requirement test.

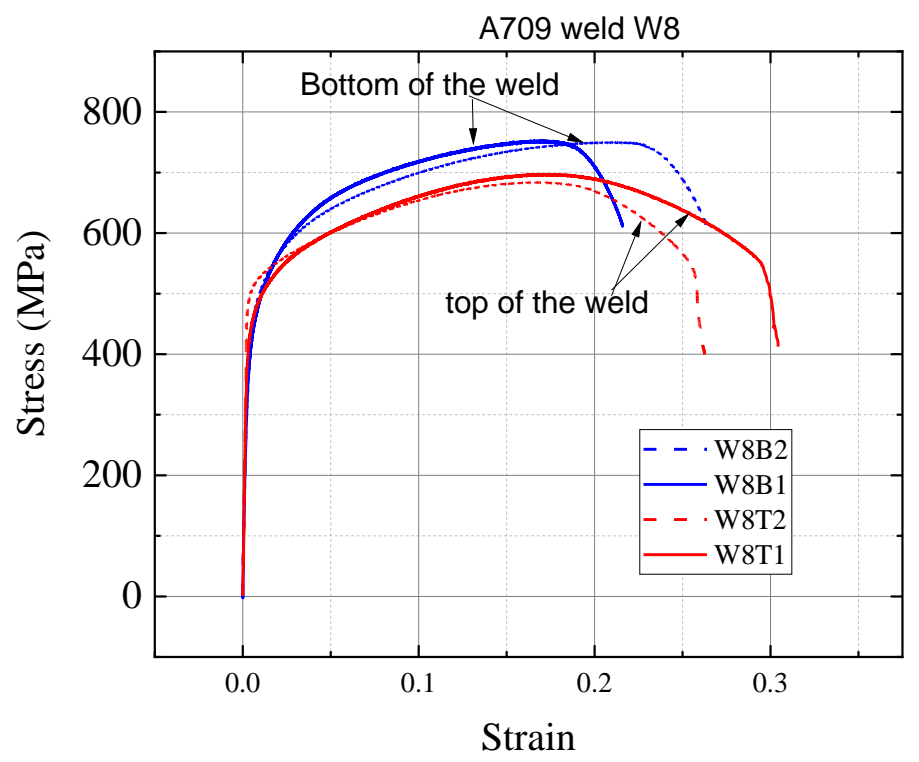

Figure 18. Room temperature cross-weld tensile results for Weld W8

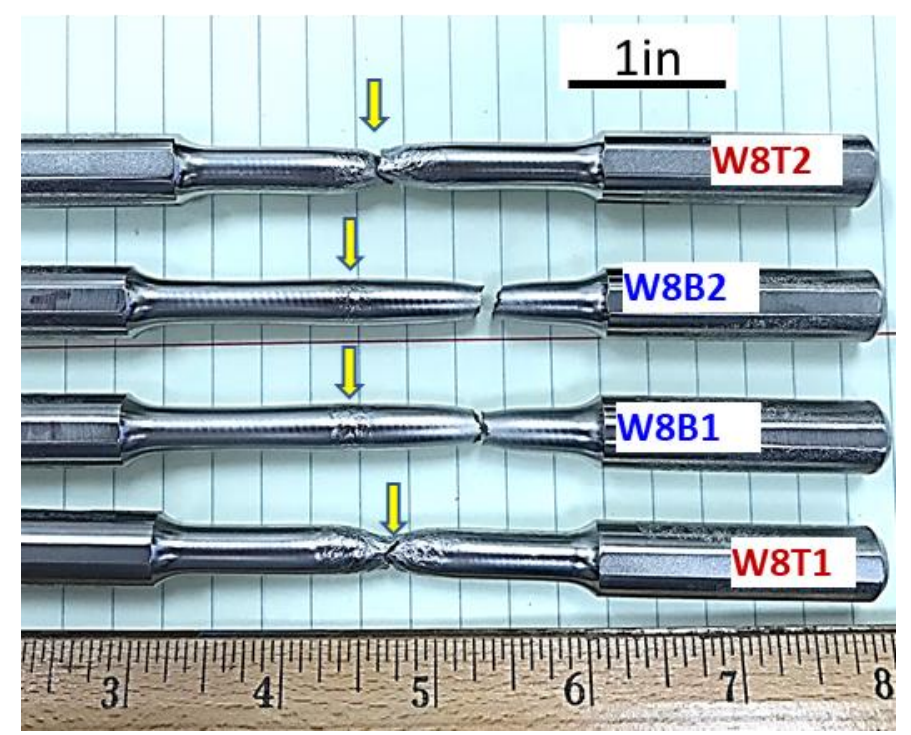

Figure 19. Photograph of the room temperature cross-weld tensile specimens from Weld W8 
Table 7. Room temperature cross-weld tensile results for Weld W8

\begin{tabular}{l|l|l}
\hline & Location of the tensile specimens & $\begin{array}{l}\text { Tensile strength, } \\
\text { MPa }\end{array}$ \\
\hline \multirow{2}{*}{$\begin{array}{l}\text { Cross-weld tensile } \\
\text { test set \#1 }\end{array}$} & Top of the weld & 697.4 \\
\cline { 2 - 3 } Cross-weld tensile & Bottom of the weld & 752.5 \\
\cline { 2 - 3 } test set \#2 & Top of the weld & 684.5 \\
\hline
\end{tabular}

\subsubsection{Microstructure characterization (W8)}

Figure 20 shows the optical image of the cross-section of the W8 weld. Three regions with weld defects were observed, and two defects on the top of the weld have the features consistent with solidification cracking. The one at bottom of the weld is a small pore, common to most welds. The large crack is about $500 \mu \mathrm{m}$. These defects are mostly located at the top half of the weld, similar to W7. The significant difference between this W8 and W7, is that the number density of the weld defects is much smaller.

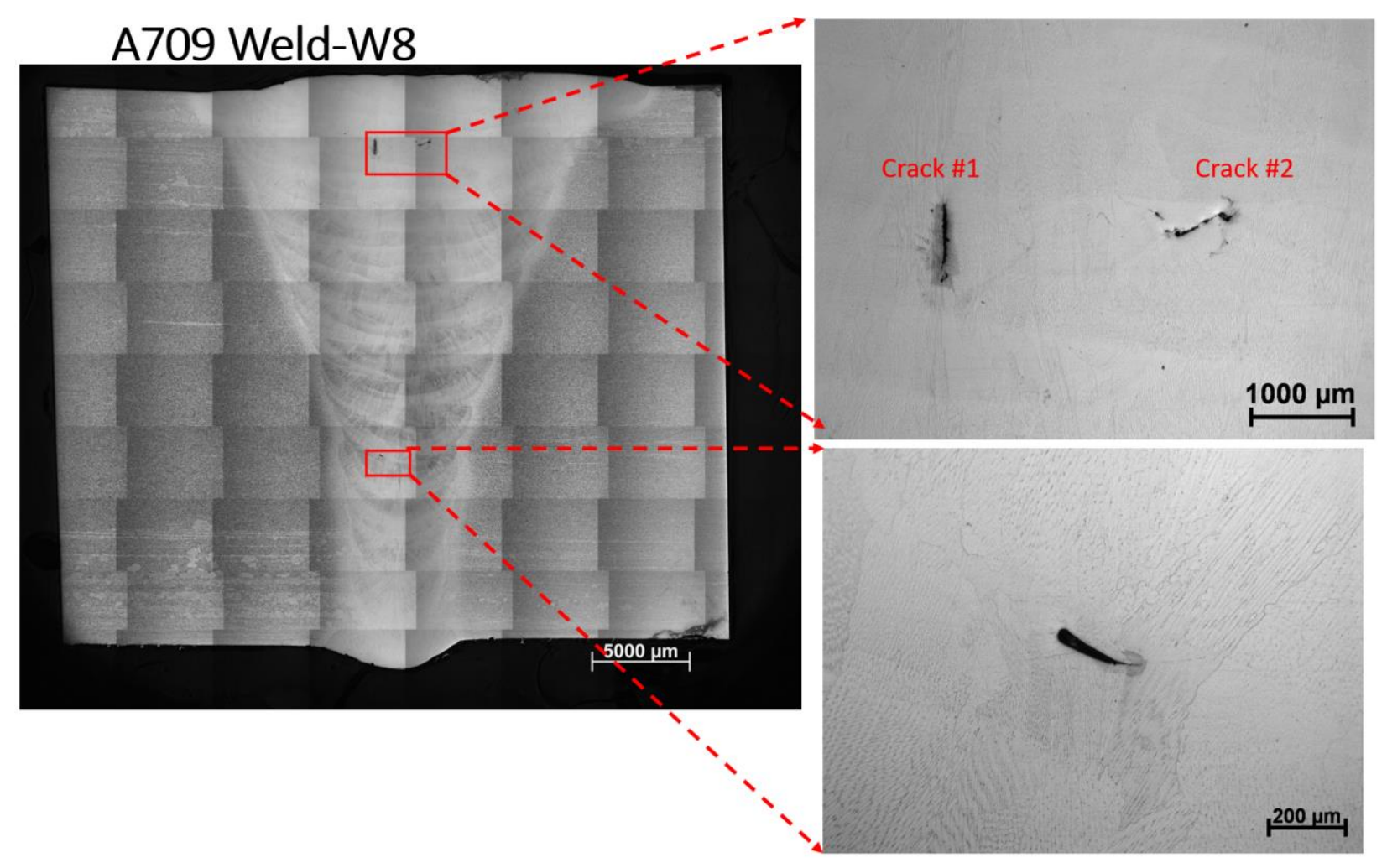

Figure 20. Cross-section view of Weld W8 


\section{FABRICATION OF ALLOY 709 WELD TO SUPPORT ALLOY 709 WELD CODE CASE TESTING}

In support of initiating creep Code Case testing of Alloy 709 weldment, production weld was fabricated in this FY 2021. The welding procedure and parameters are the same as what was developed for Weld W6 (<20wppw P). The base metal plates were the same Carlson Heat 58766 ESR1150-AH, each with the size of 15in long, 4in wide and 1.12in thick. The total length of this production weld is 15 in and can yield a total of 19 creep specimens.

A photograph of this production weld is shown in Figure 21. X-ray inspection result was acceptable with no relevant indication of welding defects. Completion of the fabrication of this production weld allows creep rupture Code Case testing of the Stress Reduction Factors required for the Alloy 709 Code Case data package.

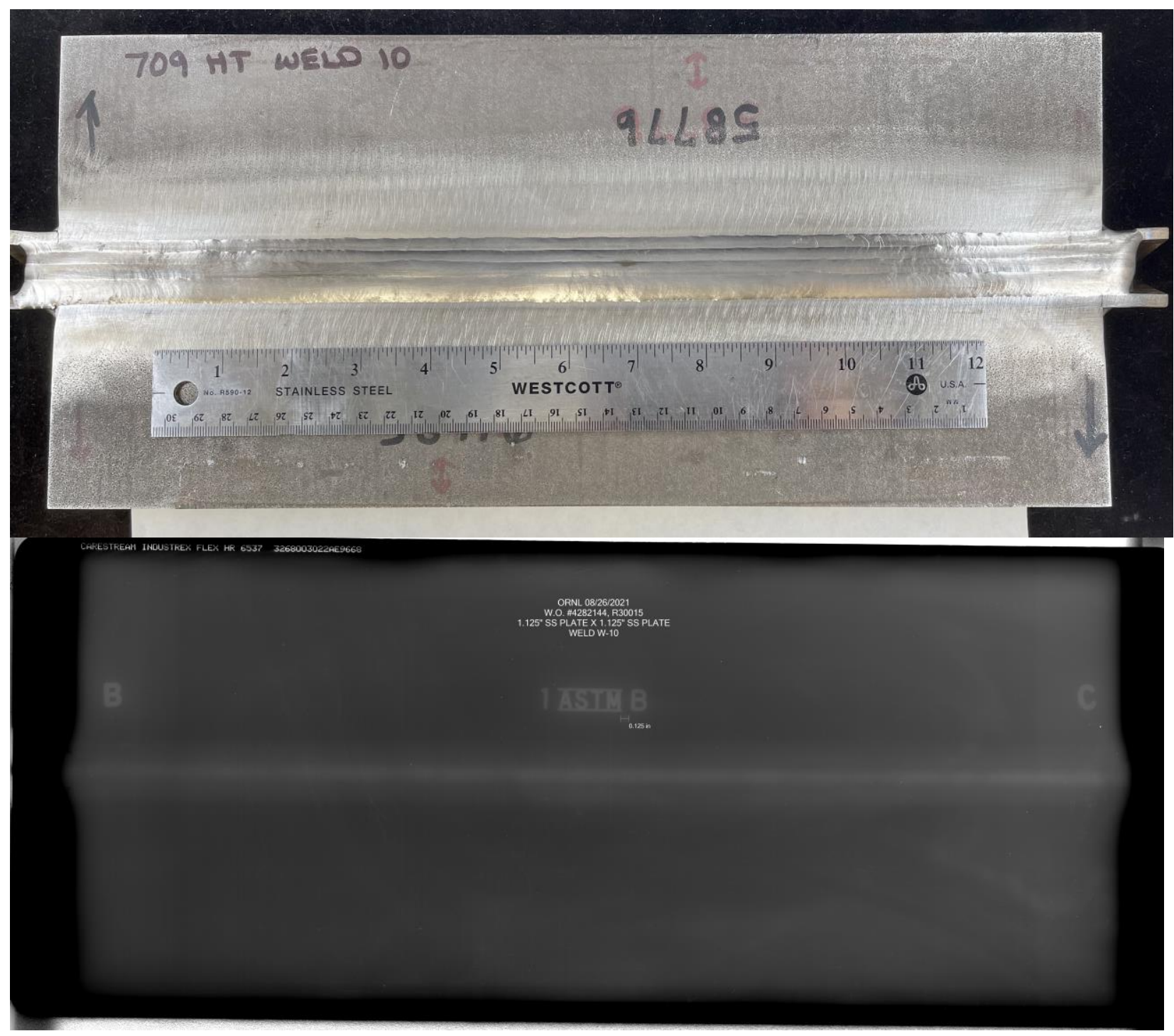

Figure 21. Photograph of the Alloy 709 production weld and X-ray NDE results 


\section{PRELIMINARY CREEP TEST ON ALLOY 709 WELDS}

Creep testing of the Alloy 709 welds are on-going for welds passed the ASME Section IX weld qualification tests. So far, creep tests have been carried out on Welds W2, W5 and W6, under creep test conditions selected for a screening assessment of the creep strength of these welds. The results from this screening test will be used to develop the creep testing matrix for the more comprehensive creep test to support the Alloy 709 Code Case data package. Table 8 lists the parameters and status of the preliminary creep test.

For comparison purposes, the Larson-Miller Parameter (LMP) was used to compare all the available creep rupture results on the Alloy 709 welds with the those on base metal ESR1100 and ESR1150-AH. The results are shown in Figure 22. In this plot, the Larson-Miller equation for calculating the LMP was based on Eq. (1):

$$
L M P=(\text { temperature }+273.15) *\left(C+\log \left(t_{r}\right)\right)
$$

where temperate is in ${ }^{\circ} \mathrm{C}$ and rupture life, $t_{r}$, is in hours, and $C$ is assumed to be a constant value of 15 .

From the limited preliminary creep rupture data on Weld W2 and W5 and the comparisons with the base metal, the rupture life of Alloy 709 cross-welds showed little or no reduction in their creep strength, except for the condition with very high stress of $330 \mathrm{MPa}$ at $600^{\circ} \mathrm{C}$. It is noted for this condition, the specimen was under high stress level beyond the yield strength, and not typical condition for creep property evaluation.

The creep testing matrix for the production weld is being developed, and the results will be used to establish the stress rupture factors for Alloy 709. It is expected the creep rupture Code Case testing of Alloy 709 welds will be initiated in FY 2022.

Table 8. Preliminary creep testing results of Alloy 709 welds

\begin{tabular}{|c|c|c|c|c|c|c|}
\hline $\begin{array}{c}\text { Alloy } \\
709 \\
\text { welds }\end{array}$ & $P$ level & $\begin{array}{c}\text { Test } \\
\text { number }\end{array}$ & $\begin{array}{l}\text { Stress, } \\
\text { MPa }\end{array}$ & $\underset{{ }^{\circ} \mathrm{C}}{\text { Temp, }}$ & Status & $\begin{array}{l}\text { Rupture } \\
\text { time, hr }\end{array}$ \\
\hline \multirow{5}{*}{ W2 } & \multirow{5}{*}{$\begin{array}{c}\text { Weld wire: P<20wppm; } \\
\text { Base meatal: ESR1100 (P: 140wppm) }\end{array}$} & 34276 & 330 & 600 & Completed & 602.7 \\
\hline & & 34325 & 330 & 600 & Completed & 378 \\
\hline & & 34455 & 330 & 600 & Completed & 353 \\
\hline & & 34456 & 27 & 925 & Completed & 342 \\
\hline & & 34458 & 80 & 775 & Completed & 2300 \\
\hline \multirow{5}{*}{ W5 } & \multirow{5}{*}{$\begin{array}{c}\text { Weld wire P: 140wppm; } \\
\text { Base meatal: ESR1100 (P: 140wppm) }\end{array}$} & $38440^{*}$ & 330 & 600 & Completed & 6.5 \\
\hline & & 38439 & 175 & 650 & Completed & $5,092.2$ \\
\hline & & 38468 & 175 & 625 & Running & -- \\
\hline & & 38467 & 150 & 650 & Running & -- \\
\hline & & 38469 & 80 & 775 & Completed & 2464.5 \\
\hline \multirow{2}{*}{ W6 } & \multirow{2}{*}{$\begin{array}{c}\text { Weld wire: } \mathrm{P}<20 w p p m ; \\
\text { Base meatal: ESR1150-AH (P: 140wppm) }\end{array}$} & 40014 & 100 & 750 & Running & -- \\
\hline & & 40017 & 50 & 800 & Running & -- \\
\hline
\end{tabular}

*This test is excluded for creep strength evaluation, due to welding defects caused short creep life. 


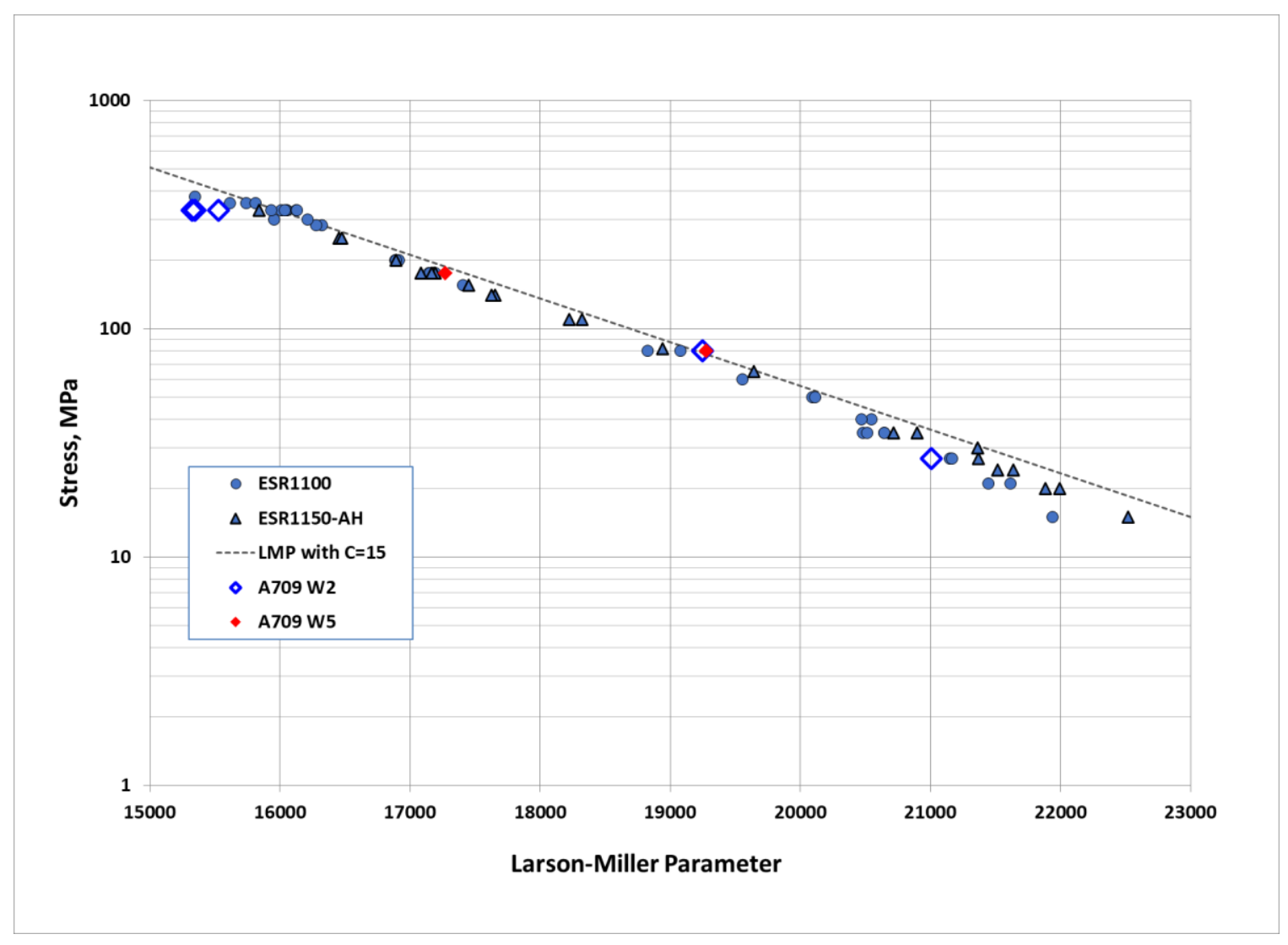

Figure 22 Comparison of creep rupture testing results of welds and base metal of Alloy 709. 


\section{SUMMARY AND FUTURE PLAN}

This report summarizes the research conducted in FY 2021 and relevant results from previous reporting periods, aimed at welding commercial heat of Alloy 709 plates of relatively high P level (140wppm) in support of ASME code qualification. Welding, code qualification tests, and associated microstructure characterization were carried out in determining the effect of $\mathrm{P}$ levels of weld wire on the weldability of the high P commercial heat of Alloy 709.

All welds produced and investigated so far in this work have been on a commercial heat of Alloy 709 (the Carlson Heat 58776) with 140wppm P. Welds with three different $P$ levels were produced by changing the P level of the weld wires from 20wppm to 140wppm.

The study found that the Carlson Heat 58776 with 140 wppm P can be welded with relative ease with a low phosphorous (20wppm) weld wire using gas tungsten arc welding process at typical welding input levels. In addition, the preliminary weld creep test showed little or no creep strength reduction in the weld region relative to that of the base metal. The success of such low $\mathrm{P}$ weld wire practice has been adopted to produce a large size weld in support of the planned comprehensive creep testing and others as part of the Alloy 709 Code Case data package. The fabrication of this large weld was completed in FY 2021.

Micro cracks or fissures are observed when the phosphorous level in the weld wire increases to 140wppm. These micro-cracks were formed due to P segregation at solidification grain boundary during the solidification of weld metal. The study found that optimizing the welding process conditions such as weld wire size and welding heat input improved the weldability, although additional R\&D is necessary to completely eliminate the micro-cracks at $140 \mathrm{wppm}$ level of P. Initial weld creep tests indicated that the micro-cracks, although acceptable to ASME Sec IX weld qualification requirement, would potentially cause premature rupture under low-temperature and high-stress creep testing conditions. On the other hand, such micro-cracks appeared to have minimal effect to weld creep strength under lower stress and higher temperature conditions. This aspect would require additional study to develop sound technical basis to support the code case qualification of Alloy 709 for ASME Sec IX.

Weld made at medium P level (estimated at $80 \mathrm{wppm}$ ) by means of twin weld wire technique showed improved weldability. Although micro-cracks were still observed, but they were less than $0.5 \mathrm{~mm}$ in size, much smaller than those found in the welds made with 140wppm weld wires. And the weld passed the ASME Sec IX weld qualification requirement. High-temperature creep testing of this weld is planed.

The research on Alloy 709 weldability in this program so far supports the strategy for successfully welding Alloy 709 having wide range of chemistries without weld solidification cracking. The strategy includes the use of low P level weld wire to weld Alloy 709 having relatively high P. It also includes segregation control and/or stress control welding techniques for P level higher than the above threshold situations. To this end, future FY R\&D plan includes quantitatively determining the threshold or the upper limit of $\mathrm{P}$ level that will not cause solidification cracking through systematic weldability study, for commonly used arc welding processes such as GTAW, shielded metal arc welding (SMAW), electronbeam welding. 


\section{BIBLIOGRAPHY}

ASME. (2019). Qualification Standard for Welding, Brazing, and Fusing Procedures; Welders; Brazers; and Welding, Brazing, and Fusing Operators. ASME Boiler and Pressure Code.

ASME. (2021). Specification for seamless ferritic and austenitic alloy-steel boiler, superheater, and heatexchanger tubes. ASME Boiler and Pressure Code, 2021 Edition.

ASTM International. (2015). Standard Specification for Seamless Ferritic and Austenitic Alloy-Steel Boiler, Superheater, and Heat-Exchanger Tubes. ASTM International.

Feng, Z., Dai, T., Kyle, D., Wang, Y., \& Wang, Y. (2020). Welding Parameters Optimization and the Fabrication of Qualified Alloy 709 Welds. Oak Ridge National Labaratory, Oak Ridge, TN.

Feng, Z., Vitek, J. M., Liu, T., \& Wang, Y. (2018). Evaluation of the Effect of Alloy Chemistry on the Susceptibility of Weld Solidification Cracking of Alloy 709 Weldment and Development of Mitigation Strategy. Oak Ridge National Laboratory. ORNL/TM-2018/965.

Feng, Z., Wang, Y., Kyle, D., \& Dai, T. (2019). Report on FY19 Fabrication and Evaluation of Weldment for Alloy 709 Commercial Heat Plates. Oak Ridge National Laboratory. ORNL/TM-2019/1320.

Natesan, Natesan, K., Zhang, X., Sham, T.-L., \& Wang, H. (2017). Report on the completion of the procurement of the first heat of Alloy 709. Argonne National Laboratory. ANL-ART-89.

NIPPON STEEL \& SUMITOMO STEEL. (2013). NF709 Material Data Sheet. Retrieved from http://www.tubular.nssmc.com/product-services/specialty-tube/product/nf709

Sham, T.-L., \& Natesan, K. (2017). Code Qualification Plan for an Advanced Austenitic Stainless Steel, Alloy 709, for Sodium Fast Reactor Structural Applications. International Conference on Fast Reactors and Related Fuel Cycles, (pp. IAEA-CN-245-74). Yekaterinburg, Russian Federation.

Yamamoto, Y. (2014). Unpublished data. Oak Ridge National Laboratory.

Zhang, X., Sham, T.-L., \& Young, G. A. (2019). Microstructural Characterization of Alloy 709 Plate Materials with Additional Heat Treatment Protocol. ANL-ART-170, Argonne National Laboratory, Lemont, IL. 